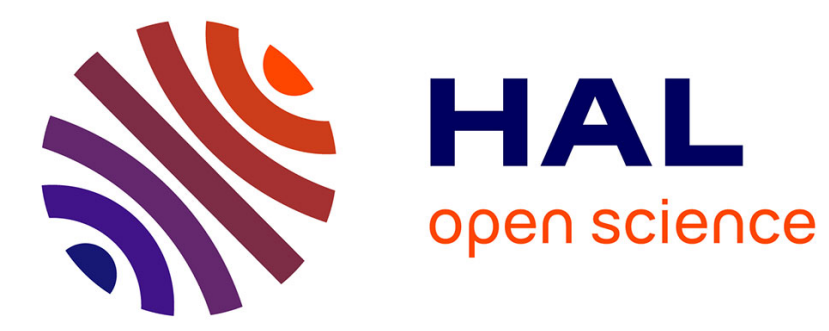

\title{
Humusica 2, article 17: Techno humus systems and global change - Three crucial questions
}

\author{
Augusto Zanella, Stefan Geisen, Jean-François Ponge, Gerard Jagers, Charles
}

Benbrook, Thomas Dilli, Andrea Vacca, Jolanta Kwiatkowska-Malina, Michaël Aubert, Silvia Fusaro, et al.

\section{To cite this version:}

Augusto Zanella, Stefan Geisen, Jean-François Ponge, Gerard Jagers, Charles Benbrook, et al.. Humusica 2, article 17: Techno humus systems and global change - Three crucial questions. Applied Soil Ecology, 2018, 122 (Part 2), pp.237-253. 10.1016/j.apsoil.2017.10.010 . hal-01672699

\section{HAL Id: hal-01672699 \\ https://hal.science/hal-01672699}

Submitted on 26 Dec 2017

HAL is a multi-disciplinary open access archive for the deposit and dissemination of scientific research documents, whether they are published or not. The documents may come from teaching and research institutions in France or abroad, or from public or private research centers.
L'archive ouverte pluridisciplinaire HAL, est destinée au dépôt et à la diffusion de documents scientifiques de niveau recherche, publiés ou non, émanant des établissements d'enseignement et de recherche français ou étrangers, des laboratoires publics ou privés. 


\section{Humusica 2, article 17: Techno humus systems and global change - Three crucial questions ${ }^{*}$}

Augusto Zanella ${ }^{\mathrm{a},{ }^{\dagger}}$, Stefan Geisen ${ }^{\mathrm{b}}$, Jean-François Ponge ${ }^{\mathrm{c}}$, Gerard Jagers ${ }^{\mathrm{d}}$, Charles Benbrook ${ }^{\mathrm{e}}$, Thomas Dilli $^{\mathrm{a}}$, Andrea Vacca ${ }^{\mathrm{f}}$, Jolanta Kwiatkowska-Malina ${ }^{\mathrm{g}}$, Michaël Aubert ${ }^{\mathrm{h}}$, Silvia Fusaro ${ }^{\mathrm{a}}$, Maria De Nobili ${ }^{\mathrm{i}}$, Giovanna Lomolino ${ }^{\mathrm{a}}$, Tiziano Gomiero ${ }^{\mathrm{j}}$

${ }^{a}$ University of Padua, Italy

${ }^{\mathrm{b}}$ Netherlands Institute of Ecology, Wageningen, The Netherlands

${ }^{\mathrm{c}}$ Muséum National d'Histoire Naturelle, Paris, France

${ }^{\mathrm{d}}$ Alterra, Wageningen, The Netherlands

${ }^{\mathrm{e}}$ Benbrook Consulting Services, Enterprise, Oregon, USA

${ }^{\mathrm{f}}$ University of Cagliari, Italy

${ }^{\mathrm{g}}$ Warsaw University of Technology, Poland

${ }^{\mathrm{h}}$ Normandie Université, Rouen, France

'University of Udine, Italy

${ }^{j}$ Fellow, Masaryk University, Brno, Czech Republic

\section{ABSTRACT}

Some soil scientists or biologists (14, one preferring anonymity) answered the three following questions:

1. Introduction)

2. Why is organic food better (e.g. tastes better, is healthier, richer in nutrients, contains less pesticide) than food produced with hydroponic or intensive farming techniques?

3. In a humipedon, are soil functioning, biodiversity and carbon content three interdependent and intersected aspects of a single ecosystem? In other words, can we treat these aspects as if they were inseparable in a humipedon?

\footnotetext{
${ }^{*}$ Background music while reading? Bob Dylan - Just Like a Woman: https://www.youtube.com/watch?v=ymmRnKaTEr8.

${ }^{\dagger}$ Corresponding author.

E-mail addresses: augusto.zanella@unipd.it (A.Zanella), S.Geisen@nioo.knaw.nl (S. Geisen), ponge@mnhn.fr (J.-F. Ponge), gerard.jagers@wur.nl (G. Jagers), thomas.dilli@studenti.unipd.it (T. Dilli), avacca@unica.it (A. Vacca), j.kwiatkowska@gik.pw.edu.pl (J. Kwiatkowska-Malina), michael.aubert@univ-rouen.fr (M. Aubert), fusaro.silvia.17@gmail.com (S. Fusaro), maria.denobili@uniud.it (M.D. Nobili), giovanna.lomolino@unipd.it (G. Lomolino), tiziano.gomiero@libero.it (T. Gomiero).
} 
4. Are agriculture and civilization (society, culture, way of life) interconnected?

All scientists expressed affirmative answers. Nuances or in depth information were also furnished. The article allows understanding the real "agronomic challenge" that predicted global change might represent for humanity. 


\section{Introduction}

This article should have been the last of a series of papers dedicated to topsoil classification and management (collected in Applied Soil Ecology - Special Issues Humusica 1 and 2). We wanted to use the information furnished with the preceding articles to promote sustainable soil exploitation and face current global change. Basically, we were discussing about how to produce good food and preserve water, as well as how to store more organic matter (carbon) in the soil in order to mitigate the greenhouse effect and increase soil biodiversity.

Tillage, pesticides, and herbicides are known to diminish the soil capacity for carbon storage. Promoting conservative and/or organic agriculture seems to be a consequent and efficient necessity. However, even if the difference in yield between organic and conventional agriculture does not seem so large (Seufert et al., 2012; Yang, 2014), we evaluated whether exclusively organic food could feed all humans. First, we focused on three fundamental research areas: 1) organic soil matter, 2) soil biodiversity, and 3) relationship between human behaviour and agriculture. Then, we collected information and prompted some maps of the distribution of the different types of humipedons on planet Earth. Finally, based on the answers received to the questions, we proposed a practical and durable exploitation of the soil, considering past and current/modern agriculture/pastoral practices, in a context of global change.

Because of the huge amount and heterogeneity of collected information, the initial article was split in three papers: Article 17. Techno humus systems and Global Change - Three crucial questions; Article 18. Techno humus systems and Global Change - Greenhouse effect, soil and agriculture; Article 19. Techno humus systems and Global Change - Conservative agriculture and $4 / 1000$ proposal.

We suggest to answer:

\section{Why is organic food better (tastes better, is healthier, richer in nutrients, poorer in} pesticides...) than food produced with hydroponic or intensive farming techniques?

\section{Augusto Zanella (University of Padua, Italy)}

During the last decade, a general agreement was made among researchers working in Italian and French scientific centres of agriculture and ecology: organic food tastes better and is healthier than that produced with conventional or intensive farming. Even if some of my colleagues are still fond of technological farming (e.g. precision agriculture, satellite assistance), they buy organic food for their babies. We are aware that: organic food is more expensive than conventional food; part of the organic food we may find in the market is organic only by name and price; reliable controls are difficult to realize; currently, the demand of organic products is increasing and income for sellers may be higher with organic than with traditional products; even informed consumers prefer to buy 
doubtful organic food than conventional products assumed to contain pesticide residues harmful to health.

When I was young, I was credulous. I thought that in a few decades we humans would have been able to rock through the space at the speed of light. Agriculture too would have been very different: we would have dedicated a lot of time to sport and amusement, while in the fields programmed robots would cultivate any sort of food good for us. In a relatively near future (we were able to understand and accelerate our own evolution: there were surgeons who believed that amygdales were non-functional glands we unfortunately inherited and easily removed them in case of repeated sore throat; even at present time there are many dentists who think that wisdom teeth should be removed for quite the same reasons, i.e. because our jaw is becoming smaller), humans were believed to develop smaller jaws, thinner bellies, amplified skulls containing larger brains, alimented by confectioned industrial, freely distributed and very nutritional chemical beverages. Today we have to face a very different reality: the less we leave our planet and atmosphere, the better our health. In dark space, temperature is $-270{ }^{\circ} \mathrm{C}$ and cosmic radiations would kill us instantly. Speed in travelling through space has increased over the past 50 years since going to the Moon, which would allow us to fly through space and to the nearest planet Mars (a desert even drier than those we have on Earth) in no less than 6 months. But the cost and risk of this operation are so high that even a consortium of the most developed countries has still not fixed a date for this historical attempt (2032? - http://www.mars-one.com/mission/roadmap). Sport time: we have a few very rich soccer players and many poor supporters who dream to become athletic and rich, too. Lunch time: if we want to eat a really good meal, we have to ask grandmother to prepare something tasteful for us. And she goes to the market (not to the modern large supermarkets, but to that served by small familiar traditional farmers or organic producers working with old manual tools), and there she buys tasteful vegetables, fruits, and meat. Then she comes back to home and prepares these products for the day after, when she gets up early and for $4-5 \mathrm{~h}$ elaborates a very good lunch for us (with incredibly simple stove and pans). Eating such grandmother-made food, one begins to doubt about the scientific capacity to discern truth and make real discoveries. One of my kids asked his grandmother to teach him how to prepare a tomato sauce. Here is the recipe she gave him:

Collect $3 \mathrm{~kg}$ of tomatoes (well-selected, ripe tomatoes), $500 \mathrm{gr}$ of onions, 2 large carrots, $1 / 4$ glass of wine vinegar, a small cup of sugar, salt, $2 / 3$ teaspoon of grated nutmeg, 8 cloves of garlic, some mustard grains, some muddled ginger, 3 branches of celery to be removed before straining the sauce.

Cut onions and carrots in slices and distribute them in a large pot with olive oil. Toss gently with salt and pepper until onions become tender (and begin to show a caramel colour). Onions must not stick to the bottom of the pot (add a little water if necessary). Add tomatoes in pieces and all the other ingredients. Boil and reduce the mixture as long as possible, paying attention that nothing sticks to the bottom of the pot.

- "How much time, grandmother?"

- "3 $\mathrm{h}$ while stirring it every $5 \mathrm{~min}$ "

Pass the sauce through a food mill. If too liquid, put it a time more on the fire until reaching the good texture. 
Bottle it while hot in small jars with large necks. Then close, turn them neck down and allow them to cool.

- "Above all, choose the right tomatoes, onions and vinegar. Next time, come to the market with me, I'll show you. And do nothing else while stirring" (Fig. 1).

With his cell phone, he took a photograph of grandmother's recipe, written on a yellow notebook page, and back home he said: "grandmother thinks we still go to the market and have a whole day for preparing a tomato sauce".

As for body transformations, unless having a real handicap, better not to finish in clinics where they would help you to transform your body.

A paper written by 18 scientists, considered as an example because being based on 343 peerreviewed publications (Barański et al., 2014), clearly shows that organically grown crops are poorer in pesticides and richer in antioxidants than corresponding conventionally grown ones. Why? Organic products are "better" than corresponding non-organic's because their confection by plants and animals is achieved with a complex living network of relationships. It is well known that agricultural organic soils are more biodiverse than those under intensive agriculture, or that a monoculture must be integrated in a biodiverse landscape in order to resist sustainable exploitation (Chen and Wong, 2016; Dauber and Miyake, 2016; Cluzeau et al., 2009; Ekroos et al., 2016; Funabashi, 2016; GathorneHardy, 2016; German et al., 2017; Hernández et al., 2014; Juárez and Diaz, 2016; Landis, 2017; Rahmann et al., 2017; Soto and Muñoz, 2002; Suso and Del Río, 2015). Living organism's relationships are the accomplishment of a long-term co-evolution. In this perspective, food, which coincides with consumable parts of organisms, corresponds to a flow of energy driving the evolution of all connected organisms (could the production of more and more food for other organisms be the final goal of natural evolution?). To defend themselves against natural pests, plants produce aromatic molecules, which give organoleptic characteristics to agricultural products (Asensi et al., 2011; Brglez Mojzer et al., 2016; Dai and Mumper, 2010; Ratnadass et al., 2012). Parasites and predators are necessary for preserving healthy herbivorous populations (Wood et al., 2007), pests may be necessary for plants, allowing them to produce more tasteful vegetables and fruits, which then may be distributed farther away, increasing the plant's chances to generate more new plants. Plants coevolve with herbivores (Fornoni, 2013; Occhipinti, 2013). We need to control co-evolving agricultural systems (Atallah et al., 2014; Salem et al., 2013; Wu and Guo, 2004).

If the biodiversity of agricultural systems indirectly influences human "alimentation" and "health", connecting the quality of food and soil biodiversity should become an efficient mean to promote a more conservative agriculture (organic, biodynamic, natural, and any other type of agriculture preserving a durable soil biodiversity) (Wood et al., 2015; Bøhn et al., 2014; Wezel et al., 2014; Dangour et al., 2009; Moreno et al., 2009). Plus, with soil biodiversity being correlated to the amount of organic matter stored in the soil, it is possible to use the soil as a sink for organic carbon, and solve two problems at once: increasing soil biodiversity and mitigating the greenhouse effect with a positive return in terms of global change (Lal, 2015; Minasny et al., 2017; Stockmann et al., 2013).

Discordant notes: Ratnadass et al. (2012) published that it is not necessarily true that vegetation diversification reduces the incidence of pests and diseases in agriculture. And no 
differences can be identified for environmental contaminants (heavy metals, as $\mathrm{Cu}$ and $\mathrm{Zn}$ ) in conventional and organic food (Magkos et al., 2006). A recent review (Galgano et al., 2016) of 140 scientific publications focusing on animal products (milk, meat, fish and eggs), comparing conventional and organic food all over the world, did not conclude that organic products are more nutritious and safer than conventional ones. For animal products, numerous researches presented contradictory results. However, these authors found a different composition of fatty acids in organic products and concluded that this is certainly an advantage for the consumer's health.

\section{Stefan Geisen (Netherlands Institute of Ecology, Wageningen, The Netherlands)}

Organic food is in principle a great idea. However, it might not be possible to feed the entirety of humans using this approach (at the moment) and organic food does not have to be better than conventional food per se. Other aspects like soil texture, weather, likelihood of pathogen infection and changes in climate have to be taken into account as they are important factors that have to be considered when planning land management.

Well-managed conventional farming practices can be more sustainable than poorly managed organic farming, as the 'organic label' does not necessarily equal sustainable or environmental friendly methods.

We should work on an integrative farming and get as close as possible to organic but in benefit of animals, farmers, consumers and, of course, soils and general environment. Food quality should be improved as a consequence.

\section{Jean-François Ponge (Muséum National d'Histoire Naturelle, Paris, France)}

About taste: do organic foods taste better? From my point of view and from my personal experience, it depends on the food because taste does not only come from the way plants were grown (or animals were bred) but also how they were harvested (at maturity or not), or how animals were treated, including the time of slaughter (whether they have suffered or not during transport or upon arrival in the slaughterhouse). Vegetables, fruits, or meat from family cultures, whether organic or not, will always have better taste. But there will always be some subjectivity in this assessment. How to avoid it except by working with a blind procedure? Not a lot of work in this direction, but you can select Fillion and Arazi (2002) on orange juice and milk: organic orange juice tastes better, but not milk (no difference). So it depends, and that is normal. For fruits, the crucial point is the degree of maturity at which they were picked off, and there is the whole problem of the distance between producers and consumers: fruits resulting from a short circuit will always taste better and those from our own orchard or neighbour's one, even more. The same for meat, of course, even if it is for other reasons (the stress caused by transport, among others).

Regarding health and what goes with it (e.g. nutritional quality, pesticides), there is a report from the Soil Association (a Scottish association) showing that the answer is yes, both regarding the nutritional value and the absence of harmful compounds (pesticides, additives):

https://www.soilassociationscotland.org/media/4920/policy report 2001 organic farming food q uality human health.pdf.

Again, the point is what we make with the products from organic farming, especially how they will be cooked (fats used, baking temperature), preserved (in the absence of additives for 
conservation, consumption must be fast or at least food must be cold-conditioned). Again, the transportation problem is crucial, so that the quality can be maintained and only when distribution channels are short.

However, Baker et al. (2002) demonstrate the existence of pesticide residues in foods from organic agriculture, although these residues are in lesser quantity (and are found less frequently) than in food from conventional farming. I did not find comparisons with hydroponics, but in my opinion it must be worse because sterile conditions are often required in these cultures and this sterility is obtained or maintained using plant protection products (Cornucopia Institute, 2015; Lages Barbosa et al., 2015; Parks, 2008; Kimura and Rodriguez-Amaya, 2003; Premuzic et al., 1998).

\section{Gerard Jagers (Department of Animal Ecology, Alterra, Wageningen, The Netherlands)}

Please consider the following contribution as my warmly meant support, while I will allow myself the role of observer.

The question that I would like to ask you is whether you think that the concept of "better" when defined the way you suggest, does also cover the overall aspects of "better" when looked at in a wide perspective? I am tempted to suggest a preliminary definition of 'better' in a broad sense e.g. like:

"the maximum amount of valued product produced, while the production is associated with the most desirable human experiences and the least degradation of resources that are nonrenewable or slowly renewable, or with the wisely decided upon degradation when resources can (potentially) be substituted." (Of course, this is only a first attempt at a definition).

How would you think about such an approach of 'better'?

If you would like to include all aspects of a broader concept of 'better' it may be that you may need more and different scientific research than you are asking for in your below mail. For example it may then become relevant to also look at the sustainability and efficiency of all the agricultural production chains involved, all the social aspects along that chain, as well as the occupation of land, the desires of people to not only work on the land but do other things, the balance between profits for some versus profits for many, the factual presence or absence of harm to humans and environment done by pesticide residues, what is better in one situation may not be so in another situation, by the role of 'homo mensurae', etc. Or simple questions such as "Would the same area of organic agriculture overall produce less or more greenhouse gases than such an area of conventional/intensive/hydroponic agriculture?" (summed activity for the different gases)?

Moreover, what may be desirable (better) at one moment in history may not be similarly desirable at another moment in human development. For example, we may soon have robotic agents (for simplicity reasons I assume they use solar energy for their activities) for carrying out the agricultural fieldwork. Would that count as 'organic'? How would you think about the possibility that the answers to your question are potentially more complex than you currently seem to suggest?

Charles Benbrook (Benbrook Consulting Services, Oregon) 
I do believe that in general and on average, well managed organic systems produce fruits and vegetables with richer, more complex flavours and enhanced nutrient profiles. The reasons are pretty clear. Conventional produce is almost always fertilized heavily with $\mathrm{N}$; high-N systems stimulate rapid growth, larger fruit size, and enhanced levels of sugars and other carbohydrates. These nutrients account for the "dilution effect," the well-known phenomenon whereby the higher the yield, the lower the nutrient concentrations, especially biochemically complex secondary plant metabolites.

So, in my judgment, the biggest contributor to enhanced flavour and nutrient levels in organic produce is the absence of excessive $\mathrm{N}$ in organic systems. When organic growers go overboard on $\mathrm{N}$, they do the same thing to their crops.

The second important reason is that organic plants have to defend themselves for insects/pathogens, and this requires stimulation of secondary plant metabolites, many of which are antioxidants.

It's another story on the animal side. For more, please see: Benbrook (2008); Barański et al. (2014) and Davis (2014).

\section{Anonymous biologist (German scientist in a Research Centre in Mantova, Italy)}

Organic food is produced with soil and plants not exposed to agricultural chemicals (mainly pesticides) and artificial fertilizers. It has many advantages:

- land may provide habitats for native species (insects, wildlife, trees, herbs, etc.);

- advantageous for workers and farmers as pesticides cause serious health problems;

- no pesticide residues on products;

- no systematic (ab)use of antibiotics in animals and thus reduced risk of antibiotic resistance in bacteria;

- no artificial conversion of $\mathrm{N}_{2}$ from the atmosphere into reactive forms of nitrogen.

Intensive and hydroponic agricultures seem being able to produce more food at lower cost. However, this way of production has many hidden costs (NOSB, 2016; USDA, 2016):

- environmental impacts (pesticide residues in ground water, surface water, death of bees, etc.);

- illness and death triggered and favoured by chronic exposure to pesticides (residents and workers);

- antibiotic resistance in bacteria caused by regular application of antibiotics (e.g. chicken, pigs);

- almost devoid of wildlife and wild plants;

- large-scale nitrogen- and phosphorus-induced environmental change; 
I think that intensive farming is cheaper because the largest majority of its costs is not covered by producers, but by tax payers (e.g. pesticides in ground water, nitrogen cycle, health costs, antibiotic resistance) and partially let in charge to future generations. If all costs were added to current production costs, intensive agriculture would be unsustainable.

I do not express my opinion about food quality, as quality is difficult to be evaluated. The used parameters may be related exclusively to intrinsic product qualities (e.g. taste, size, shape), but also to production processes (e.g. free or ranged chicken), or content of unwanted pesticides and so on (Delgado et al., 2013). As long as 'quality' is not well defined, it is not possible to compare the quality of organic and intensive agriculture foods. However, I clearly prefer organic food for all the reasons given above.

Thomas Dilli (Msc. student in Forest and Environment Sciences, University of Padua, Italy)

From just a century, chemicals were used in agriculture in order to ensure abundant harvests and to eliminate any uncertainty linked to the unpredictability of climate adversities. Once it was possible to have abundant and varied food, the focus shifted to what could be healthier, with the birth of various diets and food fads. Surely fruits and vegetables are important food to stay healthy; they should be cultivated so as to obtain the most nutritional capacity and exhibit the least amount of dangerous substances. The purpose of this short report is to compare organic and conventional (with the use of chemical products such as fertilizers and pesticides) cultivation techniques for growing fruit and vegetables. I wanted to know whether the risks for human health is higher with aliments coming from conventional compared to those coming from organic agriculture. I considered scientific publications analysing nitrate content, pesticide residues and nutritional value (with greater attention to plant secondary metabolites) of fruits and legumes. I prepared Table 1 in which plus and minus signs refer to conventional crops as the baseline for comparison. For example, vitamin C is $26 \%$ more abundant in organic crop (conventional 100\%, organic 126\%).

The increase of cases of degenerative diseases in recent decades cannot be exclusively attributed to the presence of risk factors in fruits and vegetables; however, various factors combine to cause diseases and physical stress to human body. The difference with other factors, as for instance air, soil or water pollution, is that in the case of food products, each consumer can inform himself and be able to choose the best for him and his body. As a consequence, the consumer can encourage a market (e.g. organic food) that, at least ideally, should protect not only the consumer health but even natural resources. This is especially true for the soil, the biodiversity of which is particularly sensible to pesticides and mineral fertilization (Bertrand et al., 2015; Gomiero et al., 2011; Prashar and Shah, 2016; Topoliantz et al., 2000).

\section{Andrea Vacca (University of Cagliari, Italy)}

A scientific answer to this question is quite difficult. I have made a very short and quick literature review only to see if from a scientific point of view there is an agreement in stating that organic food may be better than conventional one.

Winter and Davies (2006) in their review discussed the differences between organic foods and conventional foods with respect to food safety and nutritional composition and made clear that several qualitative differences exist. Nevertheless, while many studies demonstrated these 
qualitative differences between organic and conventional foods, it is premature to conclude that either food system is superior to the other with respect to safety or nutritional composition.

Nuňez de González et al. (2015) noted very few differences in $\mathrm{NO}_{2}{ }^{-}$concentrations of conventional and "organic"-labelled vegetables taken from 5 U.S. metropolitan cities. However, differences in $\mathrm{NO}_{3}{ }^{-}$content were apparent for some conventional and organic vegetables in different cities with the organic vegetables being lower in $\mathrm{NO}_{3}{ }^{-}$content.

According to Hoefkens et al. (2010), the health benefits of consuming organic compared to conventional foods are unclear and, in public health terms, there is insufficient evidence to recommend organic over conventional vegetables.

Contradictory to previous studies, Rembiałkowska (2016) reports that according to the recent big meta-analysis, organic food contains significantly lower levels of contaminants and higher levels of antioxidants than conventional food. Nevertheless, her conclusion is that further studies are necessary in order to confirm the tentative results and to understand the mechanisms of organic diet impact on health.

On the other hand, there is growing evidence that organic farming systems possess higher quality soils with robust microbial activity in comparison to conventionally managed systems (Niemi et al., 2008; Ge et al., 2013).

Talking about taste, I never tried to directly compare organic versus conventional food. If someone will ask me to compare two salads, an organic one versus a conventional one, just tasting them, most probably I will not be able to say which of the two is organic. Nevertheless, I will surely be able to recognize an organic salad from a conventional salad while washing and preparing them. The organic salad will be the one with snails or other small animals on it! And that makes a difference for me, besides any other consideration. The same will be with vegetables and fruits, in general.

Concerning other food, such as meat and fish, I am sure I will be able to immediately recognize meat coming from animals raised on natural pastures or fish raised commercially in tanks or enclosures. For meat and fish my taste works better than for salad, vegetables and fruits!

In conclusion, yes, I prefer organic food. Why? Because "organic" meat and fish taste much better than "industrial" ones, and because I like the small animals that I find in organic salad, vegetables, and fruits. If they like that food, why should it not be good for me as well? And, there is evidence that the soil supporting organic farming is much more "alive and healthy" than the soil supporting conventional farming. Moreover, as stated by Morgan and Murdoch (2000), the conventional chain is biased towards standardized knowledge with the effect that tacit knowledge is debased so that it cannot easily be drawn upon once this chain moves into crisis. In contrast, the organic model affords more scope for the utilization of tacit knowledge in combination with benign standardized forms. This combination aims to revalue local knowledge, local ecosystems and local identities so that farmers can once again become "knowing agents", able to exercise more autonomy and control over both their relations with other actors in the food chain and the means of production on the farm.

Is this philosophy? Yes, it is! But all choices in life are related to philosophy, isn't it? 
Jolanta Kwiatkowska-Malina (Warsaw University of Technology, Warsaw, Poland)

Organic food (legumes, fruits and meat) is better (tastes better, is healthier, richer in nutrients, poorer in pesticides, etc.) than food produced with hydroponic or intensive farming techniques. Why?

In my opinion, organic food is better than food produced with hydroponic or intensive farming techniques. However, the key factor for the future must be sustainability. Soil-based organic greenhouse systems are not sustainable in practice, whereas organic hydroponic systems are far more sustainable.

The debate about organic versus conventional farming is a difficult one with many people holding very strong views. It is important to examine the evidence and carefully think through the advantages and disadvantages of each farming system.

While industrialised agricultural systems in theory produce sufficient food to feed the world's current population, they have accomplished this feat with significant ecological and social externalities (Hazell and Wood, 2008). The organic agriculture production system shows: respect for the environment and animals, promotion of sustainable cropping methods, use of non-chemical fertilizers and pest/disease/weed control means, production of high-quality foodstuffs and no use of genetically modified (GM) crops. Ecological farming systems serve as the mechanism for maintaining and regenerating biotic interactions and, in turn, ecosystem services e.g., soil quality, nitrogen fixation, pollination, and pest control that provide critical inputs to agriculture (Kremen and Miles, 2012).

Organic plant products tend to have more dry matter, some minerals $(\mathrm{Fe}, \mathrm{Mg})$ and antioxidant micronutrients (phenols, resveratrol) while animal organic products have more polyunsaturated fatty acids (Bourn and Prescott, 2002; Ferlay et al., 2006; Olsson et al., 2006; Rembiałkowska, 2007). Regarding safety issues, $94-100 \%$ of organic food does not contain any pesticide residues, organic vegetables contain markedly less nitrates (about half) and organic cereals contain overall levels of mycotoxins comparable to conventional ones (Cornée et al., 1992; Schneweis et al., 2005).

Michaël Aubert (Normandie Université, Rouen, France)

Organic food industry is fuelled by the consumer perception, which considers that organic food is healthier (greater nutritional value and fewer toxic chemicals) than conventional one (Crinnion, 2010). However, the scientific opinion is divided on whether there are significant nutritional differences between organic and non-organic foods. Based on a meta-analysis of 343 peer-reviewed publications Barański et al. (2014) have recently concluded that compounds usually linked to a reduced risk of chronic diseases (e.g. phenolic acids, flavanones, stilbenes, flavones, flavonols), are substantially higher in organic crop-based foods than in conventional-based ones. They also highlighted that the frequency of occurrence of pesticide residues was four times higher in conventional crops than in organic ones. Nevertheless, when we consider the literature more finely, things are not quite simple according to the considered vegetables, varieties, growth seasons and nutrients or molecules used to discriminate conventional versus organic farming. As example, Gąstoł et al. (2011) comparing some nutritional values of juices made from organic and conventional apple, 
pear, blackcurrant, carrot, beetroot and celery showed the organic juices to have polyphenols and ascorbic acid contents similar to, and antioxidant activity slightly higher than conventional juices. Moreover, Hajšlová et al. (2005) showed that between-year changes, as well as variety and geographical variations, were equally or more important factors determining the quality of potatoes (nutrients and vitamins) than the farming system, i.e. organic versus conventional farming. For olive oils, Ninfali et al. (2008) showed that organic versus conventional cultivation did not affect consistently the quality (antioxidant capacity and volatile compounds) as well as the results of sensory analyses, because olive tree genotype and year-to-year changes in climate had more marked effects than agricultural practices. Similar results were found for broccoli for which seasonal changes in C-vitamin content were found to be larger than the differences between organically labelled and conventionally labelled broccoli (Wunderlich et al., 2008). In their study, Wunderlich et al. (2008) obtained their broccoli samples from supermarkets i.e. the point of consumer consumption. The absence of sharp differences in vitamin $\mathrm{C}$ concentration may come from the delay between the harvest and the selling period, as vitamin $\mathrm{C}$ is a fragile nutrient. This leads sometimes to counterintuitive results, such as a greater baking quality for conventional wheat than for organic one (Mazzoncini et al., 2015).

So, regarding the nutrient value or the organoleptic quality of organic crops versus conventional ones, no consensus emerges about the added value of organic farming. Nevertheless, studies often report (i) a lower $\mathrm{N}$ and $\mathrm{P}$ content in edible parts of organic vegetables (Barański et al., 2014; Gąstoł et al., 2011; Herencia et al., 2011) and (ii) strong changes in secondary metabolites especially those involved in the defence against diseases and pests (Brandt et al., 2011). A metaanalysis by Brandt et al. (2011) showed that in organic fruits and vegetables, the content of secondary metabolites is $12 \%$ higher than in conventional produce. The authors also highlighted that defence-related compounds were $16 \%$ higher for organic produce while other metabolites such as carotenoids or vitamin $\mathrm{C}$ were poorly impacted by farming. As defence-related secondary metabolites have previously been linked to a reduced risk of chronic diseases or certain cancers, as example, organic farming may thus benefit human health. Here again, the intuitive link between organically produced food and the reduction of a large range of common cancers due to less pesticides used in organic farming is not totally demonstrated (Bradbury et al., 2014).

So, when I wear my soil ecologist hat, I recognize beyond doubts the environmental benefits of organic farming, notably on soil, air and groundwater quality (Aneja et al., 2009; Hole et al., 2005; Pimentel et al., 2005). When I wear my consumer hat (managing a wallet), considering foregoing citations, I may wonder if the direct link between organic farming and quality of organically produced food is strongly established. One explanation to this absence of well-established links may be found in the commercial varieties actually used for agricultural production. Most of them have been selected on the basis of their productivity or of their conformation, e.g. short and round sheep legs able to easily enter the housewife ovens. Organoleptic or nutritional qualities were not always the main selection criteria. Consumer's sensitivity thus remains the last argument to shift totally or partially from conventionally produced food toward organically produced one. In my own experience, I partially shift from conventional toward organic food when I know that the production needs important amounts of pesticides such as for potatoes, apple or wine. I prefer organic wines because for the same grape variety organic wines express more the notion of "terroir" than those issuing from conventional viticulture. Finally, I remain on conventional produce when benefits are not demonstrated, such as foreggs. 


\section{Maria de Nobili (University of Udine, Italy)}

Organically grown fruits and vegetables have a much shorter shelf life than traditionally grown produce. This is due to the fact that they do not get post-harvest application of fungicides to reduce decay caused by moulds or bacteria. This not only avoids the contamination of organic produce with pesticides, but organic fruits and vegetables, being fresher, contain a larger number of vitamins and have better organoleptic properties when consumed, in spite of the fact that they may not be actually different, apart being free of pesticides, from the others.

Unfortunately, organic lettuce and leafy vegetables on the contrary, may be even less healthy to consume in large quantities than conventionally grown ones. In fact, organic farming employs massive amounts of organic manures, particularly farmyard manure. Under these conditions nitrification is fast and this causes organically grown vegetables to uptake much more nitrates.

\section{Silvia Fusaro (Young PhD, University of Padua, Italy)}

Food produced with organic or with more intensive farming systems can be compared from different points of view. From the human nutrition point of view, for example, we can find different evidences in literature. Phytochemicals, and in particular phenolic compounds, present in plant foods, may be partly responsible for health benefits in humans eating fruits and vegetables, reducing risks for several chronic diseases (Young et al., 2005). These authors did not find significant differences in phenolic agent contents in vegetables grown up in conventional or organic conditions, but just higher values of Folin's reactive phenols in one vegetable, probably due to pest attacks. Therefore, they concluded that, although the organic method alone did not seem to enhance biosynthesis of phytochemicals in vegetables, the organic farming system could provide an increased opportunity for insect attack, resulting in a higher level of total phenolic agents. The situation seems similar to that found in Fusaro (2015), analysing horticultural crops grown up under organic and conventional farming systems, especially due to a more intensive use of pesticides in conventional fields (Fusaro et al., 2016). While Sousa et al. (2005) found that tronchuda cabbages from an organic farming system presented higher phenolic contents than those from the conventional one, in Fusaro (2015) the fructose content was significantly higher in organically grown up cabbages and fructose also had an antioxidant power, making these findings partly in line with the evidences in literature. Concerning $\mathrm{Na}^{+}$and $\mathrm{NH}_{4}{ }^{+}$contents in edible crops, Schuphan (1974) found a link between the use of only mineral fertilization $[\mathrm{N} / \mathrm{P} / \mathrm{K}]$ and the increase in $\mathrm{Na}^{+}$in cabbage; moreover, as regards mineral fertilization, anhydrous ammonia is often applied as source of $\mathrm{N}$ : ammonia reacts with soil water to form the ammonium ion, which is held on the mineral/organic exchange complex (National Research Council, 1989).

Fusaro (2015) found that $\mathrm{N}, \mathrm{NO}_{2}$ - and $\mathrm{PO}_{4}{ }^{3-}$ contents were significantly higher in cabbages grown up in conventionally managedfields (also $\mathrm{NO}_{3}{ }^{-}$, but not significantly) and these crop properties are strictly linked to mineral fertilization $[\mathrm{N} / \mathrm{P} / \mathrm{K}]$ adopted in this type of farming system. The $\mathrm{NO}_{3}{ }^{-}$ ion, the main form of nitrogen supplied to crops from soil (Magkos et al., 2006), is the major precursor of the $\mathrm{NO}_{2}{ }^{-}$ion in the human body (Amr and Hadidi, 2001). Even if $\mathrm{NO}_{2}{ }^{-}$ions are instable, because they tend to link to amines to form nitrosamines, it must be remembered that nitrosamines are carcinogenic and implicated in the genesis of methemoglobinemia (Bruning-Fann and Kaneene, 1993; WHO, 1995). Worthington (2001) reviewing studies concerned with several crop nutritional properties, found that nitrates were significantly lower $(-15 \%)$ in organic with respect to 
conventional farming system, even though the variability in nitrate content probably reflects the different fertilization strategies adopted by farmers. Besides different analyses Magkos et al. (2006) depicted a complex picture concerning crop nitrate content and underlined how, except for nitrophilic vegetables, there could be many factors, irrelevant to the farming system, and that might affect it, such as soil type, planting and harvesting dates, nitrate in irrigation water, location.

As regards other element contents, Worthington (2001) found that $\mathrm{Fe}, \mathrm{P}, \mathrm{Cu}, \mathrm{Zn}$ contents were respectively $20 \%, 10 \%, 10 \%, 8 \%$ higher in organically grown up cabbages, while Fusaro (2015) found that the content of the same elements was greater in cabbages grown up in conventional farming systems. Fusaro (2015) found higher calcium and molybdenum contents in organically grown up cabbages and the same trend was found by Worthington (2001), who in particular pointed out an increase in calcium content of $28 \%$ and an increase in molybdenum content of $60 \%$ in crops coming from organic fields in comparison to those coming from conventional fields.

As regards heavy metals ( $\mathrm{Al}, \mathrm{Cd}, \mathrm{Hg}, \mathrm{Pb}$ ) Fusaro (2015) found no significant differences in contents between cabbages grown up with the two different farming systems. For this purpose, Worthington (2001) found instead that organic crop contained lower amounts of heavy metals more often than comparable conventional crops. Concerning chemical contaminants in food that result from general environmental pollution, such as $\mathrm{Cd}, \mathrm{Hg}, \mathrm{Cu}, \mathrm{Zn}, \mathrm{Pb}, \mathrm{As}$, dioxins, $\mathrm{PCBs}$, radioactive nuclides, some authors (Magkos et al., 2006) found that their absence, presence and relative amount in organic and conventional food depend mainly on farm location and not so much on management practices.

As here briefly described, surely the evaluation of nutritional differences between vegetables cultivated according to different agronomical methods is very complex and not always univocal. However, Schuphan (1974) found that generally the effects on mineral contents are also variable depending on soil types. After the analysis of data from three years of research, also Warman and Havard (1997) underlined some differences in mineral contents, although not consistent, between cabbages grown up in organic and conventional plots.

But I am starting to doubt: are we sure that we can consider food crops just as a mechanistic list of nutritional compounds or are they "living matter" and therefore have some emergent properties that characterize living systems? Can we really synthesize a food source as a nutritional table? Fusaro (2015) underlined how crop nutritional properties are strictly associated to many other bioindicators, functional indicators and features of the agroecosystem in which the crop grows. By reviewing 76 studies, Hole et al. (2005) clearly demonstrated that species abundance and/or richness tend to be higher on organic farms than on locally representative conventional farms, and moreover functional indicators seem to underline that some key ecosystem services are more efficient in organically managed fields (Fusaro, 2015). On an extreme level, while for more intensive farming systems the soil is merely a physical substrate where crops are hosted, for organic farming the soil and the whole agroecosystem contribute to the characteristics of the food crops. For these reasons, maybe considering merely the nutritional differences between organic and conventional edible crops is like seeing just "one side of the coin", since food crops are a complex concept concerning also the way of production and, of course, linked to the soil ecosystem, where crops live, and in general to the environment where we live. Therefore, in a healthy environment, a functional soil, resulting from low impact agriculture such as organic farming, can grow up not "spoiled" but self-made crops, with 
some hardly quantifiable emergent properties. It is sure that the sustainability of the food system has to be addressed from many different perspectives, in a holistic way and with a long-term perspective in mind; given the crucial role that food production plays in our life, our major concern should be to secure that farming practice guarantees the resilience of our food production system (Gomiero, 2013).

\section{Giovanna Lomolino (University of Padua, Italy)}

Organic production could be defined as an ecological production that supports biodiversity, biological cycles and soil activity (EC, 2016). It is considered as a series of cultural techniques that promote the practices that refresh, maintain and favour ecological harmony (Hazell and Wood, 2008).

The growth of organic foods has considerably increased in recent decades. At first, organic food production covered only small farms and local distribution of fresh products; nowadays, the current system of organic food is a complex combination of small and large producers, networks of local and global distributors, and a wide variety of products, including fruit, meat, dairy products, and processed food.

This rapid growth could be attributed to the consumer's response to awareness and confidence in organic food as well as to the concern about possible risks to health and environmental impact of conventional production of food.

Some food-related problems such as mad cow and foot-and-mouth diseases have lessened consumer's confidence in food in general, especially in conventional production methods using pesticides, antibiotics and other synthetic chemicals in food production (Dreezens et al., 2005). Surveys indicate that many consumers buy organic foods because they perceive health and nutritional benefits. In a survey, the main reasons that induce the consumer to buy organic foods are:

- 70\%: people avoid pesticides.

- 68\%: people consider organic products as fresher.

- 67\%: people buy organic food for health and nutritional reasons.

- 55\%: people avoid genetically modified organisms (whole foods market, in Dreezens et al., 2005).

These consumers agree to pay from $10 \%$ to $40 \%$ more for organic foods.

Pesticides: According to surveys conducted on consumers of organic products, approximately $70 \%$ of them buy these products as free of pesticides. In fact, one of the driving reasons for the production of organic foods is the lack of pesticides or their residues. The dietary exposure to the pesticide is not only limited to the intake of fruits and vegetables. Factors such as washing, peeling, baking, frying, and processing can affect the amount of pesticides available to the consumer at the time of consumption.

Certainly, some substances are permitted according to the Natl. List., but these should not contaminate soil, water and the environment. Among these products there are: soap-based herbicides; water disinfectants such as calcium hypochlorite, sodium hypochlorite and copper sulphate; insecticides such as boric acid, lime sulphur, elemental sulphur, copper sulphate and oils. 
Nutritional compounds: Many consumers consider organic food better than conventional one under nutritional point of view and often believe that the methods often used to increase the yield of conventional foods, such as the use of pesticides and fertilizers, could limit the natural ability of plants to incorporate or synthesize nutrients.

In recent years, many researchers have conducted several controlled studies to compare organic and conventional food, considering nutritional composition (Table 2). Some studies have found that organic production methods lead to an increase in nutrients, in particular organic acids and phenolic compounds, some of which may have potential beneficial effects on human health such as antioxidants. However, other studies show that there are no obvious differences in terms of nutrients between organic and conventional production methods. There are two hypotheses that explain the possible increase of organic compounds and phenolic acids in organic products. One hypothesis considers the impacts of different fertilization practices on the metabolism of plants. In conventional manufacturing methods, synthetic fertilizers make more nitrogen available to plants than organic fertilizers and could accelerate growth and development. For this reason, plant metabolism is more involved in the growth of plant structure, and this results in a reduction of secondary metabolism, responsible for the synthesis of non-essential compounds to the plant such as organic acids and polyphenols, etc.

The second hypothesis considers the plant response to environmental stress conditions such as insects and pathogens. It has been suggested that organic production, which limits the use of pesticides, can cause greater stress to the plant that synthesizes new compounds with defence properties. The increase in antioxidants such as phenolic substances could represent the plant response to agents or conditions of attack (Asami et al., 2003).

Although this second hypothesis is confirmed in numerous studies, the impact on human health of high amounts of fatty acids and polyphenols has not yet been demonstrated.

For example, some studies of organically and conventionally cultivated strawberries show that extracts from organic ones demonstrated in vitro a higher antiproliferative activity against colon cancer and breast cells, compared to conventional ones (Olsson et al., 2006; Hakkinen and Torronen, 2000).

Other studies have shown that organic tomatoes had higher levels of vitamin $\mathrm{C}$ and polyphenols (Oliveira et al., 2013; Caris-Veyrat et al., 2004).

Animal products: Differences in animal products between organic and conventional production systems were observed. Studies on milk, conducted in The Netherlands, UK, Denmark and USA have shown that animals bred in organic conditions have a higher content of $n-3$ linoleic acids and conjugated linoleic acids (CLA), compared to milk produced in conventional farming (Bloksma et al., 2008; Velimirov et al., 1992). These differences are detected especially in summer when the animals grown in organic conditions graze outdoors. Outdoor breeding, grassland with high biodiversity, low level of concentrated and no silage are key elements for beneficial milk fatty acid composition (Kusche, 2009). The French AFSSA (Lairon, 2009) reports that dry matter, minerals (Fe, $\mathrm{Mg}$ ), antioxidants (phenols) and salicylic acids are present in higher amounts in vegetable products, as well as polyunsaturated fatty acids in animal products obtained in organic conditions. 


\section{Tiziano Gomiero (Fellow, Masaryk University, Czech Republic)}

It is for more than two decades that I follow the scientific literature concerning the quality of organic food (and the quality of food in general). I think that when talking about organic agriculture and the quality of organic food, we have to address four different, but still equally important issues: (1) the nutritional quality of the food; (2) the quality of the food in terms of presence of pesticide residues, content of heavy metals, mycotoxins and bacterial contamination, and antibiotics (taste can be included, too); (3) the quality of the environment and human health, that is to say the residues of agrochemicals in the soil, the water we drink and the air we breathe, and the rise of strains of bacteria resistant to antibiotics and the appearance of new plagues (threats posed by intensive farming of animals); (4) although often overlooked, we should also address the risks that intensive agricultural practices pose on the long term to food security, environmental services, and the cultural heritage, by degrading the soil and the landscape, exhausting the water table and erasing biodiversity.

Summarizing the result of a review I carried out for Applied Soil Ecology, Humusica 3, "Food quality assessment in organic vs. conventional agricultural produce: findings and issues":

1) Concerning the nutritional quality of organic produce, the review works carried out in the last decades provided contrasting results, some studies report no differences between organic and conventional food, while later works report statistically meaningful differences in composition between organic and non-organic crops/crop-based foods. It has to be pointed out that the effectiveness of comparative exercises has been a matter of discussion among scholars. Some scholars argue that more effective and detailed guidelines should be devised for the design and reporting of both primary studies and meta-analyses.

2) Literature agrees on the fact that the consumption of organic food reduces the exposure to toxic pesticide residues and antibiotic-resistant bacteria (the spread of bacterial resistance to antibiotics is a cause of major alarm). Concerning heavy metals, mycotoxins and bacterial contamination, there are no significant differences in organic produce compared to conventional produce (with the exception of $\mathrm{Cd}$, found to be lower in organic produce, which is a positive finding).

3) By banning the use of highly toxic synthetic agrochemicals, organic agriculture greatly benefits environmental and human health. The ban on the use of transgenic organisms reduces the risks that such organisms may present for environment and human health.

4) Farming practices adopted by organic agriculture aim at protecting the soil and enriching it in organic matter. A higher content of soil organic matter enhances soil fertility, reduces soil erosion, increases water-holding ability, and preserves soil biodiversity. Preserving the soil health means preserving the fertility of the soil in the long run and increasing its resilience to extreme events (for example, soils with high organic matter content can better cope with drought). Organic agriculture is also concerned with the preservation of ecological structures (e.g. woodland, grassland) that turn out to preserve biodiversity and provide a number of ecosystem services.

Organic agriculture can provide important benefits to human health and to the environment, as well as promote a more compassionate treatment of animals. The lower yields of organic agriculture compared to conventional agriculture (minus 20-30\%) and the higher cost of organic food 
are often given as proof of its inefficiency. In some densely populated regions, organic agriculture may not be implementable on a large scale following the standards. Yet, the adoption of some agroecological practices may help reduce the use of fertilizers and toxic pesticides. In more industrialised countries, such as in EU and USA, organic agriculture may represent a much-needed alternative to conventional high-input agriculture, as the main agricultural issue that governments have been faced with is how to get rid of surplus, to the point to pay farmers for not cropping the land and subsidising the burning of a large part of the production to produce (inefficient) "green fuels".

\section{In a humipedon, are soil functioning, biodiversity and carbon content three interdependent and intersected aspects of a single ecosystem? In other words, is it reasonable to treat these elements as if they were inseparable in a humipedon?}

\section{Augusto Zanella (University of Padua, Italy)}

In soil, there is living and dead SOM (Soil Organic Matter). However, dead SOM can durably be fixed in agricultural soils only if accompanied with a large amount of living SOM. This is due to the fact that soil is a living ecosystem and that living SOM needs dead SOM for growing and stay alive.

\section{Stefan Geisen (Netherlands Institute of Ecology, Wageningen, The Netherlands)}

Dear Augusto, as you probably know, I am very much in favour of soil biodiversity and acknowledge its immense functional importance. But to be honest, I think that soil biodiversity can also reduce soil carbon and just adding soil organisms might not essentially mitigate climate change. Why not simply adding more litter on/in soils?

I still agree with a more sustainable agriculture, but sometimes well-managed conventional farming can be a way better than badly managed organic farming. I just want to raise this concern as it might be good to provide a less biased view on systems. If we eventually can achieve a real sustainable, integrated organic farming, this would be of course ideal, but intermediate steps might be a good start...

I am not sure whether climate change has always a direct negative effect on us, while beneficial microbes thrive in higher temperatures and the microbiome is not unlikely to adapt. It might be a bit too far-fetched in this work to link climate change directly to us, but there is certainly enough evidence to link it to the indirect effects we are suffering from emergent plant pathogens etc., just some thoughts.

\section{Maria de Nobili (University of Udine, Italy)}

Dear Augusto, I think that there is some dangerous confusion that needs to be clarified: soil biodiversity is not directly linked to $\mathrm{C}$ accumulation. Just think of the fact that the most obvious natural examples of carbon sinks, peat deposits, are characterized by a relatively low animal and plant biodiversity, whereas the soils of tropical rain forests that sustain the highest aboveground and belowground biodiversity in our planet are desperately low in C. My point of view on organic farming is very close to that of Stefan. I also think that while a discussion about carbon sequestration issues 
would make a very good concluding paper, a discussion on organic farming, which of course needs to involve taste, nutrition and pesticides, would be somewhat beyond Humusica at this stage.

\section{Augusto Zanella (University of Padua, Italy)}

The process of biodegradation furnishes mineral elements and functional molecules to plants. In turn, plants grow and produce dead SOM (litter and exudates) for entertaining their living source (mostly microorganisms, such as archaea, bacteria and fungi, but also all macro and meso soil organisms involved in preparing and entertaining the soil structure) of nutriments. The system grows as a whole. There is a correlation between living and dead organic matter in a healthy soil (AcostaMartínez et al., 2007; Adani et al., 2007; Annabi et al., 2007; Balabane et al., 2005; Balesdent et al., 2000, 1998; Beylich et al., 2010; Chenu and Stotsky, 2002; Henle et al., 2008; Moreno et al., 2000, 2009; Pélosi et al., 2009; Ranjard and Richaume, 2001; Schmidt et al., 2011; Six et al., 2004; Sollins et al., 1996; Tilman et al., 2012; Torsvik and Øvreås, 2002). Because soil is an ecosystem, the more the biomass, the more the cycling mass of bioelements (Crotty et al., 2016; Lange et al., 2015; Nath and Lal, 2017; Palm et al., 2014; Spurgeon et al., 2013; Tsiafouli et al., 2015). It is well known that biodiversity in tropical forests is higher than in other forests. In the former, the ecological pyramid may rise to 6-7 levels of secondary consumers; soil develops even on tree branches (epiphytes) and the chain of biodegraders may be very long even in a generally poorly biodiverse soil (Ding et al., 2016; Nadkarni, 1984). Carbon cycling is fast, and certainly more consistent than in less favourable climatic conditions. When biomass is high, soil carbon in the cycle of life should be high, too. Thus, if we want to have a high and stable average of $\mathrm{OM}$ in an agricultural soil, we need to raise its biomass levels. The SOM of "blocked" soils (submerged soils which lack oxygen, for instance) is an "out of control" mass of SOM and can rapidly disappear (drainage and oxygenation of submerged soils; fungi, bacteria, fire... can rapidly destroy this type of SOM). In natural conditions, high biodiversity means high content of energy (which imposes a high mass of bioelements cycling within the system). Smmarizing a lot of published papers, I represented with a stretched cloud of points (blue) in Figure 2 the relationship between SOM and biodiversity in a soil. In the cloud, I traced some dotted green lines (real movements imposed by climatic or artificial limitations) and a red historical trend line (result of many dynamic variations). For example, earthworms (populations dominated by Lumbricus rubellus and Aporrectodea caliginosa) density and biomass increase linearly by $14 \%$ for each $10 \%$ increase in SOM content in the model that Knight et al. (1992) proposed for pasture land.

Earthworms are not synonymous of "biodiversity" but in agricultural or pasture soils they are the major contributors to soil biodiversity and represent a large component of the stock of natural soil capital (Bertrand et al., 2015; Blouin et al., 2013; Keith and Robinson, 2012; Paustian et al., 2016). In many other studies (Acosta-Martínez et al., 2007; Adani et al., 2007; Annabi et al., 2007; Ayres et al., 2006; Balabane et al., 2005; Balesdent et al., 1998; Beylich et al., 2010; Chenu and Plante, 2006; Chenu and Stotsky, 2002; Cunningham et al., 2013; Henle et al., 2008; Kamau et al., 2017; Pélosi et al., 2009; Rahman et al., 2008; Rahmann et al., 2017; Ranjard and Richaume, 2001; Rasib et al., 2015; Schmidt et al., 2011; Six et al., 2004; Sollins et al., 1996; Tilman et al., 2012; Torsvik and Øvreås, 2002; Young et al., 2008; Sheibani and Ahangar, 2013; Torsvik and Ovreas, 2002) a positive relationship between SOM and the mass of soil microorganisms or even the stability of biogenic aggregates was suggested. As humus specialists, we know that different organic and organic-mineral horizons are inhabited by different animals (for details, refer to Humusica 1, articles 4 and 8 ). Thus, the reaction of the pedofauna to artificial addition of organic matter is not linear. With more than $30-35 \%$ of organic matter (nearly $20 \%$ of OC), an organic-mineral A horizon begins to resemble an organic $\mathrm{OH}$ horizon. 
Its fauna will move to a different equilibrium, progressively losing its large earthworms and gaining in micro-arthropods and enchytraeids, which are the typical fauna of an $\mathrm{OH}$ horizon. Following the number of individuals of a population of large earthworms, in Figure 2 we may observe a decreasing mass of them (one among the decreasing dotted green line) after $30 \%$ of SOM, as stated by Pey et al. (2014). However, when unlimited by other factors, as low pH, drought, cold temperature, etc., the biomass of a given soil (ecosystem) would continue to increase. Tracing stable isotopes, Morriën (2016) concluded his short recent review about a soil food web with a figure. In it, it clearly appears that from early to late successional systems, along a secondary succession from an agricultural system to a species-rich late-successional grassland, the soil food web becomes much more connected, complex and biodiverse. The C-flow shifts from a more bacterial-dominated energy channel (bacteria, protists, bacterivorous nematodes and earthworms) to a more fungal-dominated energy channel (fungi, fungivorous nematodes, Collembola and fungivorous mites). A direct feeding channel on the roots via root-feeding nematodes and omni-carnivorous nematodes appears. Due to more recalcitrant matter in the system, debris accumulates and stimulates the fragmenting community (earthworms, millipedes and woodlice) and the fungal community (from sugar fungi towards wood-degrading fungi), that are highly connected to the rest of the food web. Organic matter, food web, and soil functioning seems to be indissociably related.

As for the second question (are we, soil scientists, able to consider food quality in Humusica and give our opinion on this point?), if we cannot say a word on it, what can normal people ask of soil scientists? We have to suggest at least a change in mentality; especially soil scientists have a great responsibility in this domain. In the past, soil scientists taught farmers how to produce a high amount of food and humanity witnessed a huge development (especially after World War II). It was a good result. Nowadays we are so numerous that we must organise the exploitation of planetary resources as a more cautious human society. And soil is still a precious (and irreplaceable) source of food and water for us.

\section{Jean-François Ponge (Muséum National d'Histoire Naturelle, Paris, France)}

Just a recall of what we know about the role of soil biodiversity in mitigating greenhouse effects. Soil biodiversity ensures diverse functions in the soil. Among them, the distribution of soil organic matter throughout the soil profile, and the amount of carbon sequestered in the soil are under the control of soil organisms. The point is the number of organisms ensuring complementary functions (Gamfeldt et al., 2008), as could be estimated from the steps of physical, chemical and spatial change of organic matter. Physical displacement is a function. Comminution is another function. Chemical transformation another one, etc. Mull and Amphi systems are those were the physical displacement of organic matter, from organic to mineral-organic horizons is ensured more or less completely by burrowing animals such as earthworms, termites, ants, voles, moles, etc. In the absence or near absence of these organisms, the function can be at least partly ensured by the harrow, but without the complete incorporation of organic matter to mineral matter which is ensured in the intestine of earth-feeding earthworms, ants, termites, millipedes, and to a lesser extent in animals which burrow or dig in the soil while not ingesting it: moles, voles, wild boars, etc. Soil animals partly decompose organic matter and exert a priming effect in the decomposition of the remaining litter through inoculating it with specialised soil microbes while passing through their gut (Curry and Schmidt, 2007). The chemical transformation of soil organic matter, whether in animal guts or outside, is mainly ensured by micro-organisms such as fungi, bacteria, actinomycetes, etc. 
Fungi are able to move in the soil thanks to the growth of their mycelial threads, bacteria do not move easily in the soil, or only on very short distances (Holland and Coleman, 1987). Bacteria need a carrier (animal or water current) or an input of easily available nutrients in their immediate vicinity. This function can be ensured by the penetration of root apices, the excretion of mucus by earthworms, or the ingestion of soil by earthworms and further mixing with organic matter. Any consumption of soil or organic matter by animals stimulates the bacterial flora of the soil, at least temporarily (Blouin et al., 2013). Fallen leaves and needles are rapidly invaded by fungi, not by bacteria, which are mainly living in quiescent colonial form in mineral-organic (or even mineral) horizons (Foster, 1988), awaiting a local mini-disturbance which could provide resources (water, nutrients, oxygen) for their growth and activity (Kozdrój and Van Elsas, 2000).

So what about stocking versus destocking of carbon by soil in the frame of global warming? What we know is that biological activity (whether of microbes, fauna or plant roots) "burns" carbon through the respiratory metabolism. This is a function. However, another function, the burying of organic matter, exerts an opposite effect, since buried organic matter remains in a stable state and thus escapes to "burning", at least for a protracted time compared to that remaining in litter (Fontaine et al., 2007). Another function, humification, i.e. the slow transformation of organic matter, resulting from comminution by fauna, mixing with mineral matter (clay and silt particles, metal oxides) and partial oxidation and condensation, contributes to the stabilization of organic matter (Kalbitz et al., 2003; von Lützow et al., 2006), and thus is antagonist to mineralization, although both functions may be ensured by the same microbial or faunal organisms (Zech et al., 1997). What is the net result of these complementary or antagonist functions? Although no known model of carbon turnover has taken it into account, I suggest it would depend on the humus form, because the way organic matter is transformed and distributed throughout the topsoil profile is the base of the morpho-functional classification of humus forms. We already know that Mull and Amphi humus systems stock more carbon in the mineral soil (where carbon is in a stable form) than Moder or Mor (Vande Walle et al., 2001; Andreetta et al., 2011; De Nicola et al., 2014), making the appearance of thick humus layers rather misleading. We can suspect that in boreal and mountain climates, where Moder and Mor humus systems are dominant, carbon destocking will dominate over stocking, the contrary in more benign climates or on calcareous substrates, i.e. everywhere Mull and Amphi are dominant and carbon is sequestered in stable forms (Melillo et al., 2002). But we have no proof of that at the moment, waiting for models taking into account the variety of humus forms, which might contribute to "putting things in better order". The Romul_hum model of soil organic matter formation coupled with soil biota activity is a good step in this direction (Chertov et al., 2017a and b; Komarov et al., 2017).

It is also known that soil is not independent of what happens aboveground. Clearly, each time man collects vegetation it withdraws some carbon from soil needs, but this holds also for forests, not only for agricultural land. A German scientist, Bernhard Ulrich, claimed that all his life, and clearly analysed the mechanisms of soil acidification (or soil impoverishment, in other terms), his main results (mostly published in German) having been synthesized after his retirement in a book written in English (Ulrich and Sumner, 1991).

So, what to do? What we have to do is to find a compromise by preserving the soil while preserving our own resources. I think that the knowledge of humus forms would contribute to that, and the effort of Humusica in this direction is worthy of notice. Agricultural soils may differ according 
to the impact of human practices upon soil biodiversity, besides classical influences of geology and climate. This information can be grasped from the examination of topsoil structure, which clearly reflects the functions ensured by soil organisms, with a scale of decreasing integrity from macro (anecic earthworms + all others of lower size) to meso (endogeic earthworms and large enchytraeids + all others of lower size) to micro (small enchytraeids + all others of smaller size) then to massive or single-grain (only nematodes + bacteria). This descending scale reproduces in an inverted fashion what happens during soil development (Rusek, 1978). Our efforts should be to maximise functional diversity, taking into account the environmental context: Agro Mull is impossible in a boreal environment (but Agro Moder is possible), while it could be the target in more benign climates, by alleviating any processes which are detrimental to earthworms, such as deep ploughing and pesticides, and by increasing organic inputs (Paoletti, 1999; Ponge et al., 2013; Pélosi et al., 2013, 2014a and b). In this sense, organic farming seems to be the best choice, although other practices, respectful of soil biodiversity, exist, such as integrated farming (Topoliantz et al., 2000), or could be stimulated to discovery by the present book.

\section{Michaël Aubert (Normandie Université, Rouen, France)}

In the straight line of Jean-François, I think we should separate for just a short moment the questions around carbon and biodiversity in order to find the good scientific groups able to bring suitable answers. The questions deal with: does the soil have to supply all ecosystem services at the same level, e.g. C storage, biodiversity support, water purification, or primary production? The answer is no at the local scale but perhaps yes at larger ones. Scientists who can provide data at the local scale are soil scientists or soil ecologists. Scientists who can assess the feasibility of maximising all soil services at regional or larger scale are geographers.

I mean maximising soil biodiversity does not necessarily lead to C storage locally, and I fully agree with Jean-François's development. Thus (i) we have to identify the most suitable ecosystems for stocking $\mathrm{C}$ (in their standing biomass or their soil), the most suitable ecosystems for supporting biodiversity (endangered biodiversity!), the most suitable ecosystems for providing food i.e. identify the service(s) for which the ecosystem is the best. And, (ii) we have to adapt the management in order to maximise these services in a way that all other services and functions do not fall below a threshold which would be synonymous with collapse, i.e. which do not fall below levels that cannot ensure sustainable functioning in a context of changing environment. Points (i) and (ii) are in the province of soil scientists and soil ecologists. Once we have collected enough information about these two points, geographers (economists as well) will join the dance to assess if at regional or country scale land use planning is sufficiently well designed to allow a region/country to (i) have a C balance tilled toward $\mathrm{C}$ storage, (ii) allow the conservation of the whole species pool willed by past history, (iii) sustainably provide drink water of high quality, etc. More broadly and without controversy, we know that hotspots of ecosystem services and hotspots of biodiversity are not necessarily spatially superimposed and that habitat diversity leads to diversity of ecosystem services. Thus, the issue of reconciling biodiversity and $C$ storage exceeds the scale of humus forms.

Silvia Fusaro (Young PhD, University of Padua, Italy)

I'm simply a soil passionate but reading this discussion raised in me some thoughts. 
Concerning the topic of soil biodiversity- $\mathrm{C}$ accumulation, peat deposits have extreme physical-chemical conditions, while tropical forests, at global scale, could represent climax biodiversity, since they were not so affected by glaciation periods and, let me using this expression, "the time of evolution has (almost) never being reset" and therefore, in particular in tropical forests, we can see, indeed, how much biodiversity can work!

In tropical forests nutrient cycles run fast and almost the whole amount of $\mathrm{C}$ is in the green and luxuriant mass. Over there, communities of organisms are composed by many species, each with a relatively small number of individuals, because each species has its own ecological niche and this "dynamic equilibrium" needed a lot of time for being established.

To produce food, in a more and more sustainable way, maybe should we tend to the utopia of ecological equilibrium on the model of tropical forests? Yes, of course, with all the necessary mitigating circumstances and modifications linked to all the specific realities.

According to me, a good starting point to improve our food production system is to take care and improve, where possible, soil biodiversity which lives in our fields.

Even with the more innovative agronomical practices, we cannot think to substitute soil biodiversity tasks (e.g. bioturbation, improvement of soil structure, organic matter recycling, air and water circulation, microbial distribution) that are fundamental ecosystem services for free! These tasks are the product of evolution.

You can just keep in mind the "Sleeping Beauty Paradox" (Lavelle and Gilot, 1994; Lavelle, 1997): the earthworm is the "prince", the soil microflora is the "sleeping beauty" and the "kiss" is the mucus of earthworms. In particular, earthworms would generate a priming effect, that is to say a stimulation of the mineralization of soil organic matter following a supply of fresh organic matter via the mobilization of dormant microbial biomass by the addition of gut mucus. Gut mucus is a quite labile and nitrogen-rich source of energy (C/N around 6; Brown et al., 2000), which then would likely activate fast-growing microbial r-strategists (Fontaine et al., 2003; Blagodatskaya and Kuzyakov, 2008; Bernard et al., 2012). A similar process concerns root exudates. Thus, the influence on soil of harrow (or plough) and ecosystem engineers (e.g. roots, earthworms) may be similar on one side (activation of biological processes) but be different on a very important other side: living ecosystems dialogue with the soil and react to feedbacks; harrows or ploughs only move the soil. Therefore, it should be good for us to practice an agriculture that disturbs as less than possible soil biodiversity, and GOOD organic or biodynamic agriculture goes, for sure, in this direction.

By simplifying such an important concept, we could say that soil life (biodiversity) consists of matter, energy "dressed" with emergent properties and that soil life is characterized by a delicate equilibrium, a subtle harmony and integration among its parts that cannot be written in a simple balance of factors or parameters.

In my opinion, humus is linked with double yarn to soil biodiversity and therefore it is our insurance for the future. Preserving the soil means preserving soil biodiversity and they are among our own most precious resources.

Jean-François Ponge (Muséum National d'Histoire Naturelle, Paris) 
Dear Silvia, just some words to say that, in my opinion, tropical rain forests cannot be considered as the optimum of biodiversity, even though they are richer in species than all other forests in the world. First, their richness holds for plant species and animals living aboveground (mostly in the canopy), not for soil organisms, due to scarcity of organic matter. Second, they are highly fragile, most carbon and nutrients being in the biomass, not in the soil. And third, it is not true to say that tropical rain forests were not affected by past ecological crises. Pollen studies have revealed that they have undergone severe climate shifts during the Pleistocene: each glaciation period was accompanied by high aridity in the tropics. For instance, the Amazonian forest collapsed at several instances and was replaced by savanna, the only refuges being small areas in the Guiana Shield where rainfall is higher thanks to the nearby Atlantic Ocean. Model ecosystems are to be found in each area, depending on geology and climate, but there is no universal model for ecological sustainability.

\section{Stefan Geisen (Netherlands Institute of Ecology, Wageningen, The Netherlands)}

Dear Jean-François, dear all, great answer that I agree with. Some slight comments to "but without a complete incorporation of organic matter to mineral matter, as in the intestine of burrowing animals". I would argue that complete mineralization is also far from complete. Consider earthworms which often bury litter and only start processing it. Maybe change to "soil animals which partly decompose organic matter and prime the decomposition of remaining litter through inoculating it with specialised soil microbes while passing through their gut", this would then also fit well with the next sentence and explain why litter is faster decomposed when animals are around; "and shift the balance between fungi and bacteria in favour of bacteria ": this is highly depending on animals; especially micro-and mesofauna contain species that are specialised to feed on bacteria (many nematodes, mites, etc). I would not keep this part as it is not essential for the rest of the text. Also many fungi are likely mostly inactive in spore forms like bacteria, only specialised decomposers in hotspots are more active, which is similar for bacteria.

But these are small details: take into account and include what you agree with and remove the rest.

Tiziano Gomiero (Fellow, Masaryk University, Czech Republik)

Dear all, a couple of notes. I am not a soil specialist, but I am interested in soil as the foundation of the agro-food-system. I am not sure the notes fit the text, but just in case.

In natural environments (not affected by human action, such as agricultural systems), the metabolism of $\mathrm{C}$ in soil, mediated by biodiversity, is linked to $\mathrm{C}$ metabolism in the aboveground ecosystem, leading to the development and maintenance of a local pattern of biomass(C)biodiversity (climate-site-soil specific). Therefore, biodiversity in soil is functional (interlinked, there are mutual feedbacks) to the evolution of the aboveground ecosystem/biodiversity/C stock.

Human action greatly alters natural processes; therefore we should distinguish soil functions that are affected by human action from those that are not. So what about stocking versus destocking of carbon in the frame of global warming? The process of destocking depends on human action: Europe, let alone, would stock a huge amount of $\mathrm{C}$ if it would be totally covered by forests, and the 
soil would be C-enriched too, by the feedback from the aboveground ecosystem (self-reinforcing process).

Jean-François Ponge (Muséum National d'Histoire Naturelle, Paris, France)

Dear Tiziano, yes, you are right, soil is not independent of what happens aboveground. Clearly, each time man collects vegetation it withdraws some carbon from soil needs, but this holds also for forests, not only for agricultural land. A German scientist, Bernhard Ulrich, claimed that all his life, and clearly analysed the mechanisms of soil acidification (or soil impoverishment, in other terms) in his famous book: http://www.springer.com/us/book/9783642744440.

What we have to do is to find a compromise by preserving the soil while preserving our own resources. I think that knowledge of humus forms would contribute to that, and the effort of Humusica in this direction is worth of notice. Agricultural soils may differ according to the impact of human practices upon soil biodiversity, besides classical influences of geology and climate. This information can be grasped from the examination of topsoil structure, which clearly reflects the functions ensured by soil organisms, with a scale of decreasing integrity from macro (anecic earthworms + all others of lower size) to meso (endogeic earthworms and large enchytraeids + all others of lower size) to micro (small enchytraeids + all others of smaller size) then to massive or single-grain (only nematodes + bacteria). This descending scale reproduces in an inverted fashion what happens during soil development, as elegantly shown in Bohemia by Josef Rusek in: Rusek, J., 1978. Pedozootische Sukzessionen während der Entwicklung von Ökosystemen. Pedobiologia 18, 426-433. This could be added, too, I acknowledge.

Estimating biodiversity is a hard task, ands full of pitfalls. It depends on the size of the surface used for the estimate. Much more species are living in the tropics compared to out-of-the-tropics, this is true. But most of these species are dispersed in a few numbers over very large areas or on the contrary clumped. And, due to the deep shade of tree canopies (do not forget that sun rays are vertical over most of the day, thus shade is deeper in the understory) there is poor stratification in the rain forest ecosystem, except along rivers. Yes, suspended soils are the rule, being associated with epiphytic growth. This is another argument to say that life is mostly aerial, not belowground. And, at last, tropical rain forests are considered as museums for species unable to resist changing climate conditions because they have evolved in the absence of seasonal fluctuations, and because of the high moisture content of the atmosphere. Benign conditions are not good for making species able to cross ecological crises, hence high extinction rates each time a disturbance occurs. This is why tropical rain forests must be protected, but decidedly no, they cannot be considered as the optimum of life on our little blue planet.

\section{Are agriculture and civilization (the society, culture, and way of life of a particular area) interconnected?}

Augusto Zanella (University of Padua, Italy) 
As humans, we live on a planet, which turns around a star. Seen from another planet, all humans breathe the same air, and walk on the same ground. Global warming is a planetary phenomenon. We must face it at the scale of planet Earth and humankind. Internet is a sort of collective humanity brain. It can be a powerful mean of expression of mankind wishes. Internet allows speaking to all the humanity. When wanting to face a global problem, we should use it and act as a wholly interconnected humanity. Time for single independent nations is over.

In his viewpoint 3. 2017, Rattan Lal, President of the International Union of Soil Science (IUSS), wrote that "Soil scientists have, are, and must continue serving agriculture (etc.). It is essential that soil scientists seek interdisciplinary cooperation with: 1 . Health scientists and human nutritionists, 2. Pharmaceutical industry, 3. Climatologists, 4. Sedimentologists, 5. Astronomers, 6. Biogeochimists, 7. Political scientists, 8. Social scientists, 9. Economists, 10. Psychologists." He granted the first place to health scientists and human nutritionists. We liked particularly the reason for which he suggested the collaboration with psychologists: "to raise the stature of soil science for attracting the best and brightest to the soil science profession", which means for serving agriculture, linked to human health and nutrition.

Adrian Villar Rojas, an Argentinian artist, imagined a "small planet" integrating humankind, and titled it: "Where the Slaves Live". He collected stones and earth in many localities of our planet and set them in a cylindrical structure, interlacing even personal and very common objects. This strange block of nature looks like a poorly attractive "unidentified flying object". However, the more we observe it, the more we are forced to agree with the artist, who succeeded in representing how humans transform nature and how soil remains a crucial and dominating (dangerous, because strange and partially unknown?) element of this evolution influenced by human (Fig. 3).

I took advantage of the silence that followed the presentation of Adrian Villar Rojas' artwork and cut the communication (the article would have been too long). In fact, the answer to the third question is quite obvious: we need local protected agriculture, preserving local typical soils and products, and fundamental common international laws for a generalized protection of the soil and its biodiversity (essentially from erosion, overexploitation, overgrazing, concrete invasion, artificial biological migration). No time for a debate about the last point. Even for humans: instead of forcing populations to migrate - in their conditions, really, we would do exactly the same - why not mitigate the economic differences between rich and poor countries? We are trying to do it. The main problem is to persuade powerful people that they could even be happier and richer in a peaceful and more equitable world. Only very civilized societies are conscious of the primordial relationship between soil (intended as cosmopedon, aeropedon, hydropedon, humipedon, copedon, lithopedon, geopedon and symbiopedon, as expressed in Humusica 2, article 13), and mankind.

\section{References}

Acosta-Martínez, V., Mikha, M.M., Vigil, M.F., 2007. Microbial communities and enzyme activities in soils under alternative crop rotations compared to wheat-fallow for the Central Great Plains. Appl. Soil Ecol. 37, 41-52. 
Adani, F., Genevini, P., Ricca, G., Tambone, F., Montoneri, E., 2007. Modification of soil humic matter after 4 years of compost application. Waste Manag. 27, 319-324.

Aires, A., Carvalho, R., Rosa, E.A., Saavedra, M.J., 2013. Effects of agriculture production systems on nitrate and nitrite accumulation on baby-leaf salads. Food Sci. Nutr. 1, 3-7.

Amr, A., Hadidi, N., 2001. Effect of cultivar and harvest date on nitrate $\left(\mathrm{NO}_{3}\right)$ and nitrite $\left(\mathrm{NO}_{2}\right)$ content of selected vegetables grown under open field and greenhouse conditions in Jordan. J. Food Compos. Anal. 14, 59-67.

Andreetta, A., Ciampalini, R., Moretti, P., Vingiani, S., Poggio, G., Matteucci, G., Tescari, F., Carnicelli, S., 2011. Forest humus forms as potential indicators of soil carbon storage in Mediterranean environments. Biol. Fertil. Soils 47, 31-40.

Aneja, V.P., Schlesinger, W.H., Erisman, J.W., 2009. Effects of agriculture upon the air quality and climate: research policy, and regulations. Environ. Sci. Technol. 43, 4234-4240.

Annabi, M., Houot, S. Francou, Poitrenaud, C., Le Bissonnais, Y., 2007. Soil aggregate stability improvement with urban composts of different maturities. Soil Sci. Soc. Am. J. 71, 413-423.

Asami, D.K., Hong, Y.J., Barrett, D.M., Mitchell, A.E., 2003. Comparison of the total phenolic and ascorbic acid content of freeze-dried and air-dried marionberry, strawberry, and corn grown using conventional, organic, and sustainable agricultural practices. J. Agric. Food Chem. 51, 1237-1241.

Asensi, M., Ortega, A., Mena, S., Feddi, F., Estrela, J.M., 2011. Natural polyphenols in cancer therapy. Crit. Rev. Clin. Lab. Sci. 48, 197-216.

Atallah, J., Teixeira, L., Salazar, R., Zaragoza, G., Kopp, A., 2014. The making of a pest: the evolution of a fruit-penetrating ovipositor in Drosophila suzukii and related species. Proc. R. Soc. B 281, 20132840.

Ayres, E., Dromph, K.M., Bardgett, R.D., 2006. Do plant species encourage soil biota that specialise in the rapid decomposition of their litter? Soil Biol. Biochem. 38, 183-186.

Baker, B.P., Benbrook, C.M., Groth III, E., Benbrook, K.L., 2002. Pesticide residues in conventional, integrated pest management (IPM)-grown and organic foods: insights from three US data sets. Food Addit. Contamin. 19, 427-446.

Balabane, M., Chenu, C., Bureau, F., Decaens, T., Akpa, M., Hedde, M., Laval, K., Puget, P., Pawlak, B., Barray, S., Cluzeau, D., Labreuche, D., Bodet, J., Le Bissonnais, Y., Saulas, P., Bertrand, M., Guichard, L., Picard, D., Houot, S., Arrouays, D., Brygoo, Y., 2005. Restauration de fonctions et propriétés des sols de grande culture intensive. Effets de systèmes de culture alternatifs sur les matières organiques et la structure des sols limoneux et approche du rôle fonctionnel de la diversité biologique des sols (Dmostra). Rapport final, Gestion Durable des Sols, GESSOL N(A01494. https://www.researchgate.net/publication/278736562.

Balesdent, J., Besnard, E., Arrouays, D., Chenu, C., 1998. The dynamics of carbon in particle-size fractions of soil in a forest-cultivation sequence. Plant Soil 201, 49-57. 
Balesdent, J., Chenu, C., Balabane, M., 2000. Relationship of soil organic matter dynamics to physical protection and tillage. Soil Tillage Res. 53, 215-230.

Barański, M., Średnicka-Tober, D., Volakakis, N., Seal, C., Sanderson, R., Stewart, G.B., Benbrook, C., Biavati, B., Markellou, E., Giotis, C., Gromadzka-Ostrowska, J., Rembiałkowska, E., SkwarłoSońta, K., Tahvonen, R., Janovská, D., Niggli, U., Nicot, P., Leifert, C., 2014. Higher antioxidant and lower cadmium concentrations and lower incidence of pesticide residues in organically grown crops: a systematic literature review and meta-analyses. Br. J. Nutr. 112, 794-811.

Baxter, G.J., Graham, A.B., Lawrence, J.R., Wiles, D., Paterson, J.R., 2001. Salicylic acid in soups prepared from organically and non-organically grown vegetables. Eur. J. Nutr. 40, 289-292.

Benbrook, C.M., 2004. Minimizing Pesticide Dietary Exposure through the Consumption of Organic Food. The Organic Center for Education and Promotion, Washington, D.C. https://www.organic-center.org/reportfiles/PesticideExposureReport.pdf.

Benbrook, C.M., 2008. The impacts of yield on nutritional quality: lessons from organic farming. https://www.organic-center.org/reportfiles/Hort Soc Colloquim July 2007 FINAL.pdf.

Bernard, L., Chapuis-Lardy, L., Razafimbelo, T., Razafindrakoto, M., Pablo, A.L., Legname, E., Poulain, J., Bruls, T., O’Donohue, M., Brauman, A., Chotte, J.L., Blanchart, E., 2012. Endogeic earthworms shape bacterial functional communities and affect organic matter mineralization in a tropical soil. ISME J. 6, 213-222.

Bertrand, M., Barot, S., Blouin, M., Whalen, J., de Oliveira, T., Roger-Estrade, J., 2015. Earthworm services for cropping systems: a review. Agron. Sustain. Dev. 35, 563-567.

Beylich, A., Oberholzer, H.R., Schrader, S., Höper, H., Wilke, B.M., 2010. Evaluation of soil compaction effects on soil biota and soil biological processes in soils. Soil Tillage Res. 109, 133-143.

Blagodatskaya, E., Kuzyakov, Y., 2008. Mechanisms of real and apparent priming effects and their dependence on soil microbial biomass and community structure: critical review. Biol. Fert. Soils. 45, 115-131.

Bloksma, J., Adriaansen-Tennekes, R., Huber, M., Van de Vijver, L.P.L., Baars, T., De Wit, J., 2008. Comparison of organic and conventional raw milk quality in the Netherlands. Biol. Agric. Hortic. 26, 69-83.

Blouin, M., Hodson, M.E., Delgado, E.A., Baker, G., Brussaard, L., Butt, K.R., Dai, J., Dendooven, L., Peres, G., Tondoh, J.E., Cluzeau, D., Brun, J.J., 2013. A review of earthworm impact on soil function and ecosystem services. Eur. J. Soil Sci. 64, 161-182.

Bøhn, T., Cuhra, M., Traavik, T., Sanden, M., Fagan, J., Primicerio, R., 2014. Compositional differences in soybeans on the market: glyphosate accumulates in Roundup Ready GM soybeans. Food Chem. 153, 207-215.

Bourn, D., Prescott, J., 2002. A comparison of the nutritional value, sensory qualities and food safety of organically and conventionally produced foods. Crit. Rev. Food Sci. Nutr. 42, 1-34. 
Bradbury, K.E., Balkwill, A., Spencer, E.A., Roddam, A.W., Reeves, G.K., Green, J., Key, T.J., Beral, V., Pirie, K., 2014. Organic food consumption and the incidence of cancer in a large prospective study of women in the United Kingdom. Br. J. Cancer 110, 2321-2326.

Brandt, K., Leifert, C., Sanderson, R., Seal, C.J., 2011. Agroecosystem management and nutritional quality of plant foods: the case of organic fruits and vegetables. Crit. Rev. Plant Sci. 30, 177197.

Brglez Mojzer, E., Knez Hrnčič, M., Škerget, M., Knez, Ž., Bren, U., 2016. Polyphenols: extraction methods, antioxidative action, bioavailability and anticarcinogenic effects. Molecules 21, 901.

Brown, G.G., Barois, I., Lavelle, P., 2000. Regulation of soil organic matter dynamics and microbial activity in the drilosphere and the role of interactions with other edaphic functional domains. Eur. J. Soil Biol. 36, 177-198.

Bruning-Fann, C.S., Kaneene, J.B., 1993. The effects of nitrate, nitrite and Nitroso compounds on human health: a review. Vet. Hum. Toxicol. 35, 521-538.

Carbonaro, M., Mattera, M., Nicoli, S., Bergamo, P., Cappelloni, M., 2002. Modulation of antioxidant compounds in organic vs conventional fruit (peach, Prunus persica L., and pear, Pyrus communis L.). J. Agric. Food Chem. 50, 5458-5462.

Caris-Veyrat, C., Amiot, M.J., Tyssandier, V., Grasselly, D., Buret, M., Mikolajczak, M., Guilland, J.C., Bouteloup-Demange, C., Borel, P., 2004. Influence of organic versus conventional agricultural practice on the antioxidant microconstituent content of tomatoes and derived purees: consequences on antioxidant plasma status in humans. J. Agric. Food Chem. 52, 6503-6509.

Chen, R.Z., Wong, M.-H., 2016. Integrated wetlands for food production. Environ. Res. 148, 429-442.

Chenu, C., Plante, A.F., 2006. Clay-sized organo-mineral complexes in a cultivation chronosequence: revisiting the concept of the primary organo-mineral complex. Eur. J. Soil Sci. 57, 596-607.

Chenu, C., Stotsky, G., 2002. Interactions between microorganisms and soil particles: an overview. In: Huang, P.M., Bollag, J.M., Senesi, M. (Eds.), Interactions Between Soil Particles and Microorganisms: Impact on the Terrestrial Ecosystem. Wiley, Chichester, pp. 3-40.

Chertov, O., Komarov, A., Shaw, C., Bykhovets, S., Frolov, P., Shanin, V., Grabarnik, P., Priputina, I., Zubkova, E., Shashkov, M., 2017a. Romul-Hum: a model of soil organic matter formation coupling with soil biota activity. II. Parameterisation of the soil food web biota activity. Ecol. Modell. 345, 125-139.

Chertov, O., Shaw, C., Shashkov, M., Komarov, A., Bykhovets, S., Shanin, V., Grabarnik, P., Frolov, P., Kalinina, O., Priputina, I., Zubkova, E., 2017b. Romul-Hum: a model of soil organic matter formation coupling with soil biota activity: III. Parameterisation of earthworm activity. Ecol. Modell. 345, 140-149.

Cluzeau, D., Pérès, G., Guernion, M., Chaussod, R., Cortet, J., Fargette, M., Martin-Laurent, F., Mateille, T., Pernin, C., Ponge, J.F., Ruiz-Camacho, N., Villenave, C., Rougé, L., Mercier, V., 
Bellido, A., Cannavacciuolo, M., Piron, D., Arrouays, D., Boulonne, L., Jolivet, C., Lavelle, P., Velasquez, E., Plantard, O., Walter, C., Foucaud-Lemercier, B., Tico, S., Giteau, J.L., Bispo, A., 2009. Intégration de la biodiversité des sols dans les réseaux de surveillance de la qualité des sols: exemple du programme pilote à l'échelle régionale, le RMQS BioDiv. Étude Gestion Sols $16,187-201$.

Cornée, J., Lairon, D., Velema, J., Guyader, M., Berthezene, P., 1992. An estimate of nitrate, nitrite and $\mathrm{N}$ - nitrosodimethy-lamine $\mathrm{n}$ in French food products or food groups. Sci. Alim. 12, 155197.

Cornucopia Institute, 2015. The Organic Hydroponics Dichotomy: Can a Soil-Less Growing System Be "Organic"? https://www.cornucopia.org/HydroponicsWhitePaper.pdf.

Crinnion, W.J., 2010. Organic foods contain higher levels of certain nutrients, lower levels of pesticides, and may provide health benefits for the consumer. Altern. Med. Rev. 15, 4-12.

Crotty, F.V., Fychan, R., Sanderson, R., Rhymes, J.R., Bourdin, F., Scullion, J., Marley, C.L., 2016. Understanding the legacy effect of previous forage crop and tillage management on soil biology, after conversion to an arable crop rotation. Soil Biol. Biochem. 103, 241-252.

Cunningham, S.A., Attwood, S.J., Bawa, K.S., Benton, T.G., Broadhurst, L.M., Didham, R.K., McIntyre, S., Perfecto, I., Samways, M.J., Tscharntke, T., Vandermeer, J., Villard, M.A., Young, A.G., Lindenmayer, D.B., 2013. To close the yield-gap while saving biodiversity will require multiple locally relevant strategies. Agric. Ecosyst. Env. 173, 20-27.

Curry, J.P., Schmidt, O., 2007. The feeding ecology of earthworms: a review. Pedobiologia 50, 463477.

Dai, J., Mumper, R.J., 2010. Plant phenolics: extraction, analysis and their antioxidant and anticancer properties. Molecules 15, 7313-7352.

Dangour, A., Dodhia, S., Hayter, A., Aikenhead, M.A., Allen, E., Lock, K., Uauy, R., 2009. Comparison of Composition (Nutrients and Other Substances) of Organically and Conventionally Produced Foodstuffs: A Systematic Review of the Available Literature. London School of Hygiene and Tropical Medicine, London.

Dauber, J., Miyake, S., 2016. To integrate or to segregate food crop and energy crop cultivation at the landscape scale? Perspectives on biodiversity conservation in agriculture in Europe. Energy Sustain. Soc. 6, 25.

Davis, D., 2014. Declining fruit and vegetable nutrient composition: what is the evidence? HortScience 44, 15-19.

De Nicola, C., Zanella, A., Testi, A., Fanelli, G., Pignatti, S., 2014. Humus forms in a Mediterranean area (Castelporziano Reserve, Rome, Italy): classification, functioning and organic carbon storage. Geoderma 235-236, 90-99. 
Delgado, C., Crisosto, G.M., Heymann, H., Crisosto, C.H., 2013. Determining the primary drivers of liking to predict consumers' acceptance of fresh nectarines and peaches. J. Food Sci. 78, 605614.

Ding, Y., Liu, G., Zang, R., Zhang, J., Lu, X., Huang, J., 2016. Distribution of vascular epiphytes along a tropical elevational gradient: disentangling abiotic and biotic determinants. Sci. Rep. 6, 19706.

Dreezens, E., Martijn, C., Tenbult, P., Kok, G., Vries, N., 2005. Food and values: an examination of values underlying attitudes toward genetically modified- and organically grown food products. Appetite 44, 115-122.

EC (European Commission), 2016. Organic Certification. European Commission, DG Agriculture and Rural Development, Unit Agricultural Modelling and Outlook, Brussels. http://ec.europa.eu/agriculture/organic/organic-farming/what-is-organicfarming/organiccertification en.

Ekroos, J., Ödman, A.M., Andersson, G.K.S., Birkhofer, K., Herbertsson, L., Klatt, B.K., Olsson, O., Olsson, P.A., Persson, A.S., Prentice, H.C., Rundlöf, M., Smith, H.G., 2016. Sparing land for biodiversity at multiple spatial scales. Front. Ecol. Evol. 3, 145.

Ferlay, A., Martin, B., Pradel, P., Coulon, J.B., Chilliard, Y., 2006. Influence of grass-based diets on milk fatty acid composition and milk lipolytic system in Tarentaise and Montbeliarde cow breeds. J. Dairy Sci. 89, 4026-4041.

Fillion, L., Arazi, S., 2002. Does organic food taste better? A claim substantiation approach. Nutr. Food Sci. 32, 153-157.

Flis, B., Zimnoch-Guzowska, E., Mankowski, D., 2012. Correlations among yield, taste, tuber characteristics and mineral contents of potato cultivars grown at different growing conditions. J. Agric. Sci. 4, 197-207.

Fontaine, S., Mariotti, A., Abbadie, L., 2003. The priming effect of organic matter: a question of microbial competition. Soil Biol. Biochem. 35, 837-843.

Fontaine, S., Barot, S., Barré, P., Bdioui, N., Mary, B., Rumpel, C., 2007. Stability of organic carbon in deep soil layers controlled by fresh carbon supply. Nature 450, 277-280.

Fornoni, J., 2013. Herbivores can select for mixed defensive strategies in plants. New Phytol. 197, 576.

Foster, R.C., 1988. Microenvironments of soil microorganisms. Biol. Fertil. Soil 6, 189-203.

Funabashi, M., 2016. Synecological farming: theoretical foundation on biodiversity responses of plant communities. Plant Biotechnol. 33, 213-234.

Fusaro, S., 2015. Evaluation, maintenance and improvement of biodiversity for environmental protection and crop. Doctorate Thesis, Università degli Studi di Padova, Padua. 
Fusaro, S., Gavinelli, F., Sommaggio, D., Paoletti, M.G., 2016. Higher efficiency in organic than in conventional management of biological control in horticultural crops in north-eastern Italy. Biol. Control 97, 89-101.

Gąstoł, M., Domagała-Świątkiewicz, I., Krośniak, M., 2011. Organic versus conventional: a comparative study on quality and nutritional value of fruit and vegetable juices. Biol. Agric. Hortic. 27, 310-319.

Galgano, F., Tolve, R., Colangelo, M.A., Scarpa, T., Caruso, M.C., Yildiz, F., 2016. Conventional and organic foods: a comparison focused on animal products. Cogent. Food Agric. 2, 1142818.

Gamfeldt, L., Hillebrand, H., Jonsson, P.R., 2008. Multiple functions increase the importance of biodiversity for overall ecosystem functioning. Ecology 89, 1223-1231.

Gathorne-Hardy, A., 2016. The sustainability of changes in agricultural technology: the carbon, economic and labour implications of mechanisation and synthetic fertiliser use. Ambio 45 , 885-894.

Ge, T., Chen, X., Yuan, H., Li, B., Zhu, H., Peng, P., Li, K., Jones, D.L., Wu, J., 2013. Microbial biomass, activity, and community structure in horticultural soils under conventional and organic management strategies. Eur. J. Soil Biol. 58, 122-128.

German, R.N., Thompson, C.E., Benton, T.G., 2017. Relationships among multiple aspects of agriculture's environmental impact and productivity: a meta-analysis to guide sustainable agriculture. Biol. Rev. 92, 716-738.

Gomiero, T., 2013. Alternative land management strategies and their impact on soil conservation. Agriculture 3, 464-483.

Gomiero, T., Pimentel, D., Paoletti, M.G., 2011. Environmental impact of different agricultural management practices: conventional vs organic agriculture. Crit. Rev. Plant Sci. 30, 95-124.

Hajšlová, J., Schulzová, V., Slanina, P., Janné, K., Hellenäs, K.E., Andersson, C.H., 2005. Quality of organically and conventionally grown potatoes: four-year study of micronutrients, metals, secondary metabolites, enzymic browning and organoleptic properties. Food Addit. Contam. $22,514-534$.

Hakkinen, S.H., Torronen, A.R., 2000. Content of flavonols and selected phenolic acids in strawberries and Vaccinium species: influence of cultivar, cultivation site and technique. Food Res. Int. 33, 517-524.

Hazell, P., Wood, S., 2008. Drivers of change in global agriculture. Phil. Trans. R. Soc. B 363, 495-515.

Henle, K., Alard, D., Clitherow, J., Cobb, P., Firbank, L., Kull, T., McCracken, D., Moritz, R.F.A., Niemelä, J., Rebane, M., Wascher, D., Watt, A., Young, J., 2008. Identifying and managing the conflicts between agriculture and biodiversity conservation inEurope: a review. Agric. Ecosyst. Env. $124,60-71$. 
Herencia, J.F., García-Galavís, P.A., Dorado, J.A.R., Maqueda, C., 2011. Comparison of nutritional quality of the crops grown in an organic and conventional fertilized soil. Sci. Hort. 129, 882888.

Hernández, T., Chocano, C., Moreno, J.L., García, C., 2014. Towards a more sustainable fertilization: combined use of compost and inorganic fertilization for tomato cultivation. Agric. Ecosyst. Environ. 196, 178-184.

Hoefkens, C., Sioen, I., Baert, K., De Meulenaer, B., De Henauw, S., Vandekinderen, I., Devlieghere, F., Opsomer, A., Verbeke, W., Van Camp, J., 2010. Consuming organic versus conventional vegetables: the effect on nutrient and contaminant intakes. Food Chem. Toxicol. 48, 30583066.

Hole, D.G., Perkins, A.J., Wilson, J.D., Alexander, I.H., Grice, P.V., Evans, A.D., 2005. Does organic farming benefit biodiversity? Biol. Conserv. 122, 113-130.

Holland, E.A., Coleman, D.C., 1987. Litter placement effects on microbial and organic matter dynamics in an agroecosystem. Ecology 68, 425-433.

Juárez, E., Diaz, M., 2016. Exploring the causes of high biodiversity of Iberian dehesas: the importance of wood pastures and marginal habitats. Agrofor. Syst. 90, 87-105.

Kalbitz, K., Schmerwitz, J., Schwesig, D., Matzner, E., 2003. Biodegradation of soil-derived dissolved organic matter as related to its properties. Geoderma 113, 273-291.

Kamau, S., Barrios, E., Karanja, N.K., Ayuke, F.O., Lehmann, J., 2017. Soil macrofauna abundance under dominant tree species increases along a soil degradation gradient. Soil Biol. Biochem. $112,35-46$.

Keith, A.M., Robinson, D.A., 2012. Earthworms as natural capital: ecosystem service providers in agricultural soils. Econ. J. 2, 91-99.

Kimura, M., Rodriguez-Amaya, D.B., 2003. Carotenoid composition of hydroponic leafy vegetables. J. Agric. Food Chem. 51, 2603-2607.

Knight, D., Elliott, P.W., Anderson, J.M., Scholefield, D., 1992. The role of earthworms in managed, permanent pastures in Devon, England. Soil Biol. Biochem. 24, 1511-1517.

Komarov, A., Chertov, O., Bykhovets, S., Shaw, C., Nadporozhskaya, M., Frolov, P., Shashkov, M., Shanin, V., Grabarnik, P., Priputina, I., Zubkova, E., 2017. Romul-Hum: a model of soil organic matter formation coupling with soil biota activity. I. Problem formulation, model description, and testing. Ecol. Modell. 345, 113-124.

Kozdrój, J., Van Elsas, J.D., 2000. Response of the bacterial community to root exudates in soil polluted with heavy metals assessed by molecular and cultural approaches. Soil Biol. Biochem. 32, 1405-1417.

Kremen, C., Miles, A., 2012. Ecosystem services in biologically diversified versus conventional farming systems: benefits, externalities and trade-offs. Ecol. Soc. 17, 40. 
Kusche, D., 2009. Organic milk and nutritional benefits for the consumer. http://www.icrof.org/pdf/fgh Kusche.pdf

Lages Barbosa, G., Almeida Gadelha, F.D., Kublik, N., Proctor, A., Reichelm, L., Weissinger, E., Wohlleb, G.M., Halden, R.U., 2015. Comparison of land, water, and energy requirements of lettuce grown using hydroponic vs conventional agricultural methods. Int. J. Environ. Res. Public Health 12, 6879-6891.

Lairon, D., 2009. Nutritional quality and safety of organic food: a review. Agron. Sustain. Dev. 30, 3341.

Lal, R., 2015. Restoring soil quality to mitigate soil degradation. Sustainability 7, 5875-5895.

Landis, D.A., 2017. Designing agricultural landscapes for biodiversity-based ecosystem services. Basic Appl. Ecol. 18, 1-12.

Lange, M., Eisenhauer, N., Sierra, C.A., Bessler, H., Engels, C., Griffiths, R.I., Mellado-Vázquez, P.G., Malik, A.A., Roy, J., Scheu, S., Steinbeiss, S., Thomson, B.C., Trumbore, S.E., Gleixner, G., 2015. Plant diversity increases soil microbial activity and soil carbon storage. Nature Commun. 6, 6107.

Lavelle, P., Gilot, C., 1994. Priming effects of macroorganisms on microflora: a key process of soil function? In: Ritz, K., Dighton, J., Giller, K. (Eds.), Beyond the Biomass. Wiley-Sayce, Chichester, pp. 176-181.

Lavelle, P., 1997. Faunal activities and soil processes: adaptive strategies that determine ecosystem function. Adv. Ecol. Res. 27, 93-132.

von Lützow, M., Kögel-Knabner, I., Ekschmitt, K., Matzner, E., Güggenberger, G., Marschener, B., Flessa, H., 2006. Stabilization of organic matter in temperate soils: mechanisms and their relevance under different soil conditions: a review. Eur. J. Soil Sci. 57, 426-445.

Magkos, F., Arvaniti, F., Zampelas, A., 2003. Organic food: nutritious food or food for thought? A review of the evidence. Int. J. Food Sci. Nutr. 54, 357-371.

Magkos, F., Arvaniti, F., Zampelas, A., 2006. Organic food: buying more safety or just peace of mind? a critical review of the literature. Crit. Rev. Food Sci. Nutr. 46, 23-56.

Mazzoncini, M., Antichi, D., Silvestri, N., Ciantelli, G., Sgherri, C., 2015. Organically vs conventionally grown winter wheat: effects on grain yield, technological quality, and on phenolic composition and antioxidant properties of bran and refined flour. Food Chem. 175, 445-451.

Melillo, J.M., Steudler, P.A., Aber, J.D., Newkirk, K., Lux, H., Bowles, F.P., Catricala, C., Ahrens, T., Morrisseau, S., 2002. Soil warming and carbon-cycle feedbacks to the climate system. Science 298, 2173-2176.

Mikkonen, T., Määttä, K.R., Hukkanen, A.T., Kokko, H.I., Törrönen, A.R., Kärenlampi, S.O., Karjalainen, R.O., 2001. Flavonol content varies among black currant cultivars. J. Agric Food Chem. 49, $3274-3277$. 
Minasny, B., Malone, B.P., McBratney, A.B., Angers, D.A., Arrouays, D., Chambers, A., Chaplot, V., Chen, Z.S., Cheng, K., Das, B.S., Field, D.J., Gimona, A., Hedley, C.B., Hong, S.Y., Mandal, B., Marchant, B.P., Martin, M., McConkey, B.G., Mulder, V.L., O'Rourke, S., Richer-de-Forges, A.C., Odeh, I., Padarian, J., Paustian, K., Pan, G., Poggio, L., Savin, I., Stolbovoy, V., Stockmann, U., Sulaeman, Y., Tsui, C.C., Vågen, T.G., Van Wesemael, B., Winowiecki, L., 2017. Soil carbon 4 per mille. Geoderma 292, 59-86.

Mitchell, A.E., Hong, Y.J., Koh, E., Barrett, D.M., Bryant, D.E., Denison, R.F., Kaffka, S., 2007. Ten-year comparison of the influence of organic and conventional crop management practices on the content of flavonoids in tomatoes. J. Agric. Food Chem. 55, 6154-6159.

Moreno, B., Garcia-Rodriguez, S., Cañizares, R., Castro, J., Benítez, E., 2009. In southeastern Spain: long-term effect of soil management on biological indicators of soil quality. Agric. Ecosyst. Environ. 131, 333-339.

Moreno, G., Gonzalez-Bornay, G., Pulido, F., Lopez-Diaz, M.L., Bertomeu, M., Morgan, K., Murdoch, J., 2000. Organic vs. conventional agriculture: knowledge: power and innovation in the food chain. Geoforum 31, 159-173.

Morgan, K., Murdoch, J., Organic vs. conventional agriculture: knowledge, power and innovation in the food chain. Geoforum 31, 2000, 159-173.

Morriën, E., 2016. Understanding soil food web dynamics, how close do we get? Soil Biol. Biochem. $102,10-13$.

Nadkarni, N.M., 1984. Epiphyte biomass and nutrient capital of a neotropical elfin forest. Biotropica $16,249-256$.

Nath, A.J., Lal, R., 2017. Effects of tillage practices and land use management on soil aggregates and soil organic carbon in the north Appalachian region, USA. Pedosphere 27, 172-176.

Niemi, R.M., Vepsäläinen, M., Walleniu s, K., Erkomaa, K., Kukkonen, S., Palojärvi, A., Vestberg, M., 2008. Conventional versus organic cropping and peat amendment: impacts on soil microbiota and their activities. Eur. J. Soil Biol. 44, 419-428.

Ninfali, P., Bacchiocca, M., Biagiotti, E., Esposto, S., Servili, M., Rosati, A., Montedoro, G., 2008. A 3year study on quality, nutritional and organoleptic evaluation of organic and conventional extra-Virgin olive oils. J. Am. Oil Chem. Soc. 85, 151-158.

NOSB (National Organic Standards Board), 2016. National Organic Standards Board, Crops Subcommittee Proposal, Hydroponic/Aquaponics/Bioponics, September 6, 2016. https://www.ams.usda.gov/sites/default/files/media/CSHydroponicsBioponicsProposalNov2 016.pdf.

Nuňez de González, M.T., Osburn, W.N., Hardin, M.D., Longnecker, M., Garg, H.K., Bryan, N.S., Keeton, J.T., 2015. A survey of nitrate and nitrite concentrations in conventional and organiclabeled raw vegetables at retail. J. Food Sci. 80, C942-C949. 
Nunez-Delicado, E., Sanchez-Ferrer, A., Garcia-Carmona, F.F., Lopez-Nicolas, J.M., 2005. Effect of organic farming practices on the level of latent polyphenol oxidase in grapes. J. Food Sci. 70, C74-C78.

Occhipinti, A., 2013. Plant coevolution: evidences and new challenges. J. Plant Interact. 8, 188-196.

Oliveira, A.B., Moura, C.F., Gomes-Filho, E., Marco, C.A., Urban, L., Miranda, M.R.A., 2013. The impact of organic farming on quality of tomatoes is associated to increased oxidative stress during fruit development. PLoS ONE 8, e56354.

Olsson, M.E., Andersson, C.S., Oredsson, S., Berglund, R.H., Gustavsson, K.E., 2006. Antioxidant levels and inhibition of cancer cell proliferation in vitro by extracts from organically and conventionally cultivated strawberries. J. Agr. Food Chem. 54, 1248-1255.

Palm, C., Blanco-Canqui, H., DeClerck, F., Gatere, L., Grace, P., 2014. Conservation agriculture and ecosystem services: an overview. Agric. Ecosyst. Environ. 187, 87-105.

Paoletti, M.G., 1999. The role of earthworms for assessment of sustainability and as bioindicators. Agr. Ecosyst. Environ. 74, 137-155.

Parks, S., 2008. Pesticide residues in hydroponic lettuce. http://ausveg.com.au/intranet/technicalinsights/docs/VG07165.pdf.

Paustian, K., Lehmann, J., Ogle, S., Reay, D., Robertson, G.P., Smith, P., 2016. Climate-smart soils. Nature 532, 49-57.

Pélosi, C., Bertrand, M., Roger-Estrade, J., 2009. Earthworm community in conventional, organic and direct seeding with living mulch cropping systems. Agron. Sustain. Dev. 29, 287-295.

Pélosi, C., Toutous, L., Chiron, F., Duns, F., Hedde, M., Muratet, A., Ponge, J.F., Salmon, S., Makowski, D., 2013. Reduction of pesticide use can improve earthworm populations in wheat crops in a European temperate region. Agr. Ecosyst. Environ. 181, 223-230.

Pélosi, C., Barot, S., Capowiez, Y., Hedde, M., Vandenbulcke, F., 2014a. Pesticides and earthworms: a review. Agron. Sustain. Develop. 34, 199-228.

Pélosi, C., Pey, B., Hedde, M., Caro, G., Capowiez, Y., Guernion, M., Peigné, J., Piron, D., Bertrand, M., Cluzeau, D., 2014b. Reducing tillage in cultivated fields increases earthworm functional diversity. Appl. Soil Ecol. 83, 79-87.

National Research Council, 1989. Alternative Agriculture. National Academies Press, Washington, D.C.

Pey, B., Nahmani, J., Auclerc, A., Capowiez, Y., Cluzeau, D., Cortet, J., Decaëns, T., Deharveng, L., Dubs, F., Joimel, S., Briard, C., Grumiaux, F., Laporte, M.A., Pasquet, A., Pélosi, C., Pernin, C., Ponge, J.F., Salmon, S., Hedde, M., 2014. Current use and future needs for soil invertebrate functional traits in community ecology. Basic Appl. Ecol. 15, 194-206. 
Pimentel, D., Hepperly, P., Hanson, J., Douds, D., Seidel, R., 2005. Environmental, energetic, and economic comparisons of organic and conventional farming systems. BioScience $55,573-$ 582.

Ponge, J.F., Pérès, G., Guernion, M., Ruiz-Camacho, N., Cortet, J., Pernin, C., Villenave, C., Chaussod, R., Martin-Laurent, F., Bispo, A., Cluzeau, D., 2013. The impact of agricultural practices on soil biota: a regional study. Soil Biol. Biochem. 67, 271-284.

Prashar, P., Shah, S., 2016. Impact of fertilizers and pesticides on soil microflora in agriculture. In: Lichtfouse, E. (Ed.), Sustainable Agriculture Reviews, Volume 19. Springer, Cham, pp. 331361.

Premuzic, Z., Bargiela, M., Garcia, A., Rendina, A., lorio, A., 1998. Calcium, iron, potassium, phosphorus, and vitamin $C$ content of organic and hydroponic tomatoes. HortScience 33, 255-257.

Rahman, M.H., Okubo, A., Sugiyama, S., Mayland, H.F., 2008. Physical, chemical and microbiological properties of an Andisol as related to land use and tillage practice. Soil Tillage Res. 101, 1019.

Rahmann, G., Reza Ardakani, M., Bàrberi, P., Boehm, H., Canali, S., Chander, M., David, W., Dengel, L., Erisman, J.W., Galvis-Martinez, A.C., Hamm, U., Kahl, J., Köpke, U., Kühne, S., Lee, S.B., Løes, A.K., Moos, J.H., Neuhof, D., Nuutila, J.T., Olowe, V.,Oppermann, R., Rembiałkowska, E., Riddle, J., Rasmussen, I.A., Shade, J., Sohn, S.M., Tadesse, M., Tashi, S., Thatcher, A., Uddin, N., von Fragstein und Niemsdorff, P., Wibe, A., Wivstad, M., Wenliang, W., Zanoli, R., 2017. Organic Agriculture 3.0 is innovation with research. Org. Agric. 7, 169-197.

Ranjard, L., Richaume, A., 2001. Quantitative and qualitative microscale distribution of bacteria in soil. Res. Microbiol. 152, 707-716.

Rasib, N.A.A., Zakaria, Z., Fahrurrazi Tompang Mohammad Rahman, R.A., Othman, H., 2015. Characterisation of biochemical composition for different types of spent mushroom substrate in Malaysia. Malaysian J. Anal. Sci. 19, 41-45.

Ratnadass, A., Fernandes, P., Avelino, J., Habib, R., 2012. Plant species diversity for sustainable management of crop pests and diseases in agroecosystems: a review. Agron. Sustain. Dev. $32,273-303$.

Rembiałkowska, E., 2003. Organic farming as a system to provide better vegetable quality. Acta Hort. 604, 473-479.

Rembialłkowska, E., 2007. Quality of plant products from organic agriculture. J. Sci. Food Agric. 87, 2757-2762.

Rembiałkowska, E., 2016. Organic food: effect on nutrient composition. In: Caballero, B., Finglas, P.M., Toldrá, F. (Eds.), Encyclopedia of Food and Health. Academic Press, Kidlington, pp. 171177. 
Ren, H., Endo, H., Hayashi, T., 2001. Antioxidative and antimutagenic activities and polyphenol content of pesticide-free and organically cultivated green vegetables using water-soluble chitosan as a soil modifier and leaf surface spray. J. Sci. Food Agric. 81, 1426-1432.

Rusek, J., 1978. Pedozootische sukzessionen während der entwicklung von Ökosystemen. Pedobiologia 18, 426-433.

Salem, M., Kohler, J., Wurst, S., Rillig, M.C., 2013. Earthworms can modify effects of hydrochar on growth of Plantago lanceolata and performance of arbuscular mycorrhizal fungi. Pedobiologia 56, 219-224.

Schmidt, M.W.I., Torn, M.S., Abiven, S., Dittmar, T., Guggenberger, G., Janssens, I.A., Kleber, M., Kögel-Knabner, I., Lehmann, J., Manning, D.A.C., Nannipieri, P., Rasse, D.P., Weiner, S., Trumbore, S.E., 2011. Persistence of soil organic matter as an ecosystem property. Nature $478,49-56$.

Schneweis, I., Meyer, K., Ritzmann, M., Hoffmann, P., Dempfle, L., Bauer, J., 2005. Influence of organically or conventionally produced wheat on health, performance and mycotoxin residues in tissues and bile of growing pigs. Arch. Anim. Nutr. 59, 155-163.

Schuphan, W., 1974. Nutritional value of crops as influenced by organic and inorganic fertilizer treatments. Qual. Plant. 23, 333-358.

Seufert, V., Ramankutty, N., Foley, J.A., 2012. Comparing the yields of organic and conventional agriculture. Nature 485, 229-232.

Shams, A.S., 2012. Effect of mineral, organic and bio-fertilizers on growth, yield, quality and sensory evaluation of Kohlrabi. Res. J. Agric. Biol. Sci. 8, 305-314.

Sheibani, S., Ahangar, A.G., 2013. Effect of tillage on soil biodiversity. J. Novel Appl. Sci. 2, 273-281.

Six, J., Bossuyt, H., Degryze, S., Denef, K., 2004. A history of research on the link between (micro)aggregates, soil biota, and soil organic matter dynamics. Soil Tillage Res. 79, 7-31.

Sollins, P., Homann, P., Caldwell, B.A., 1996. Stabilization and destabilization of soil organic matter: mechanisms and controls. Geoderma 74, 65-105.

Soto, G., Muñoz, C., 2002. Consideraciones teóricas y prácticas sobre el compost, y su empleo en la agricultura orgánica. Manejo Integr. Plagas y Afroecología 65, 123-129.

Sousa, C., Valentão, P., Rangel, J., Lopes, G., Pereira, J.A., Ferreres, F., Seabra, R.M., Andrade; P.B., 2005. Influence of two fertilization regimens on the amounts of organic acids and phenolic compounds of tronchuda cabbage (Brassica oleracea L. var costata DC). J. Agric. Food Chem. 53, 9128-9132.

Spurgeon, D.J., Keith, A.M., Schmidt, O., Lammertsma, D.R., Faber, J.H., 2013. Land-use and landmanagement change: relationships with earthworm and fungi communities and soil structural properties. BMC Ecol. 13, 46. 
Stockmann, U., Adams, M.A., Crawford, J.W., Field, D.J., Henakaarchchi, N., Jenkins, M., Minasny, B., McBratney, A.B., Courcelles, V., Courcelles, V. de R. de, Singh, K., Wheeler, I., Abbott, L., Angers, D.A., Baldock, J., Bird, M., Brookes, P.C., Chenu, C., Jastrow, J.D., Lal, R., Lehmann, J., O'Donnell, A.G., Parton, W.J., Whitehead, D., Zimmermann, M., 2013. The knowns, known unknowns and unknowns of sequestration of soil organic carbon. Agric. Ecosyst. Environ. 164, 80-99.

Suso, M.J., del Río, R., 2015. A crop-pollinator inter-play approach to assessing seed production patterns in Faba bean under two pollination environments. Euphytica 201, 231-251.

Tilman, D., Reich, P.B., Isbell, F., 2012. Biodiversity impacts ecosystem productivity as much as resources, disturbance, or herbivory. Proc. Natl. Acad. Sci. USA 109, 10394-10397.

Toor, R.K., Savage, G.P., Heeb, A., 2006. Influence of different types of fertilisers on the major antioxidant components of tomatoes. J. Food Compos. Anal. 19, 20-27.

Topoliantz, S., Ponge, J.F., Viaux, P., 2000. Earthworm and enchytraeid activity under different arable farming systems, as exemplified by biogenic structures. Plant Soil 225, 39-51.

Torsvik, V., Øvreås, L., 2002. Microbial diversity and function in soil: from genes to ecosystems. Curr. Opin. Microbiol. 5, 240-245.

Tsiafouli, M.A., Thébault, E., Sgardelis, S.P., De Ruiter, P.C., Van der Putten, W.H., Birkhofer, K., Hemerik, L., De Vries, F.T., Bardgett, R.D., Brady, M.V., Bjornlund, L., Jørgensen, H.B., Christensen, S., Hertefeldt, T.D., Hotes, S., Gera Hol, W.H., Frouz, J., Liiri, M., Mortimer, S.R., Setälä, H., Tzanopoulos, J., Uteseny, K., Pižl, V., Stary, J., Wolters, V., Hedlund, K., 2015. Intensive agriculture reduces soil biodiversity across Europe. Glob. Chang. Biol. 21, 973-985.

Ulrich, B., Sumner, M.E., 1991. Soil Acidity. Springer, Berlin.

USDA (United States Department of Agriculture), 2016. Hydroponic and Aquaponic Task Force Report.

https://www.ams.usda.gov/sites/default/files/media/2016\%20Hydroponic\%20Task\%20Force \%20Report.PDF.

Vande Walle, I., Mussche, S., Samson, R., Lust, N., Lemeur, R., 2001. The above- and belowground carbon pools of two mixed deciduous forest stands located in East-Flanders (Belgium). Ann. Sci. For. 58, 507-517.

Veberic, R., Trobec, M., Herbinger, K., Hofer, M., Grill, D., Stampar, F., 2005. Phenolic compounds in some apple (Malus domestica Borkh) cultivars of organic and integrated production. J. Sci. Food Agric. 85, 1687-1694.

Velimirov, A., Plochberger, K., Huspeka, U., Schott, W., 1992. The influence of biologically and conventionally cultivated food on the fertility of rats. Biol. Agric. Hortic. 8, 325-337.

Vrček, I.V., Čepo, D.V., Rašić, D., Peraica, M., Žuntar, I., Bojić, M., Mendaš, G., Medić-Šarić, M., 2014. A comparison of the nutritional value and food safety of organically and conventionally produced wheat flours. Food Chem. 143, 522-529. 
WHO, World Health Organization, 1995. Evaluation of certain food additives and contaminants. WHO Technical Report No. 859.

http://apps.who.int/iris/bitstream/10665/37246/1/WHO TRS 859.pdf.

Warman, P.R., Havard, K.A., 1997. Yield, vitamin and mineral contents of organically and conventionally grown carrots and cabbage Agric. Ecosyst. Environ. 61, 155-162.

Wezel, A., Casagrande, M., Celette, F., Vian, J.F., Ferrer, A., Peigné, J., 2014. Agroecological practices for sustainable agriculture: a review. Agron. Sustain. Dev. 34, 1-20.

Winter, K., Davis, S.F., 2006. Organic foods. J. Food Sci. 71, R117-R124.

Wood, C.L., Byers, J.E., Cottingham, K.L., Altman, I., Donahue, M.J., Blakeslee, A.M.H., 2007. Parasites alter community structure. Proc. Natl. Acad. Sci. USA 104, 9335-9339.

Wood, S.A., Karp, D.S., DeClerck, F., Kremen, C., Naeem, S., Palm, C.A., 2015. Functional traits in agriculture: agrobiodiversity and ecosystem services. Trends Ecol. Evol. 30, 531-539.

Worthington, V., 2001. Nutritional quality of organic versus conventional fruits, vegetables and grains. J. Altern. Compl. Med. 7, 161-173.

Wu, K.M., Guo, Y.Y., 2004. The evolution of cotton pest management practices in China. Annu. Rev. Entomol. 50, 31-52.

Wunderlich, S.M., Feldman, C., Kane, S., Hazhin, T., 2008. Nutritional quality of organic, conventional, and seasonally grown broccoli using vitamin $\mathrm{C}$ as a marker. Int. J. Food Sci. Nutr. 59, 34-45.

Yang, S., 2014. Can organic crops compete with industrial agriculture? http://news.berkeley.edu/2014/12/09/organic-conventional-farming-yield-gap/.

Young, J.E., Zhao, X., Carey, E.E., Weltl, R., et al., 2005. Phytochemical phenolics in organically grown vegetables. Mol. Nutr. Food Res. 49, 1136-1142.

Young, I.M., Crawford, J.W., Nunan, N., Otten, W., Spiers, A., 2008. Microbial distribution in soils: physics and scaling. In: Sparks, D. (Ed.), Advances in Agronomy, Volume 100. Academic Press, Amsterdam, pp. 81-121.

Zech, W., Senesi, N., Guggenberger, G., Kaiser, K., Lehmann, J., Miano, T.M., Miltner, A., Schroth, G., 1997. Factors controlling humification and mineralization of soil organic matter in the tropics. Geoderma 79, 117-161. 


\section{Figure captions}

Fig. 1. Cooking science. a) Grandma working in a traditional kitchen; b) Modern kitchen example (free-to-use or share web image).

Fig. 2. Modelled responses of earthworm population biomass and density, average diameter of soil aggregates, microbial and fungal biomass to increments in SOM content. Many papers suggest a positive relationship between biological parameters and SOM. The relationship is represented with a general red straight line emerging in the long run from many wavy dotted green lines. These lasts would imitate the real answers of a general living soil ecosystem to climatic and anthropic pressures. With different values and amplitudes, the model is proposed for all the variables listed on the ordinate axis. It corresponds to a rough relationship between these variables and SOM. It allows understanding a general process of pedogenesis. (For interpretation of references to colour in this figure legend, the reader is referred to the web version of this article).

Fig. 3. "Where the slaves live". Adrian Villar Rojas, Fondation Louis Vuitton, Paris (2014). Supplementary information at: http://www.fondationlouisvuitton.fr/en/collection/oeuvres/where the slaveslive.html (Photograph: A. and C. Kersalé). 


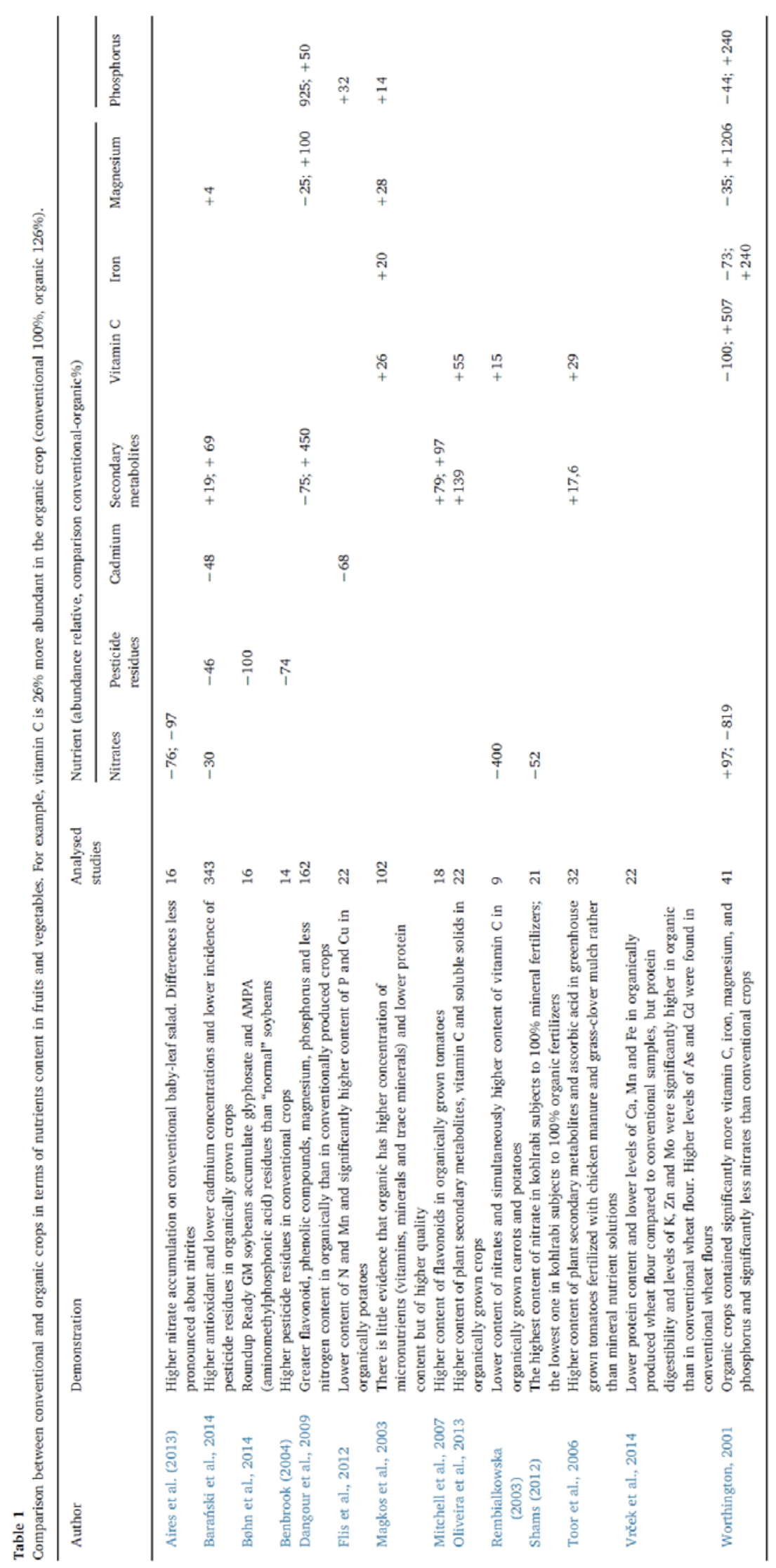


Table 2

From Winter and Davis 2006: Summary of recent studies comparing organic and conventional foods with respect of nutrients levels.

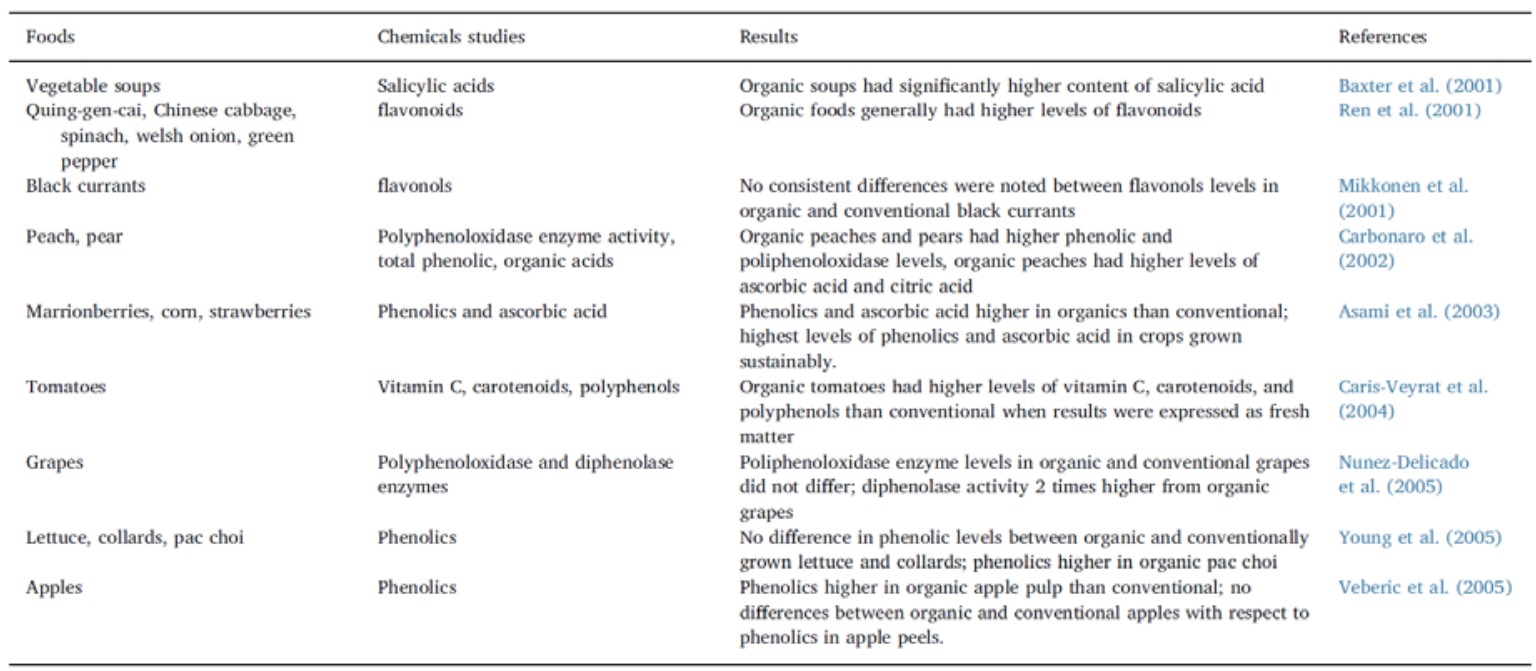




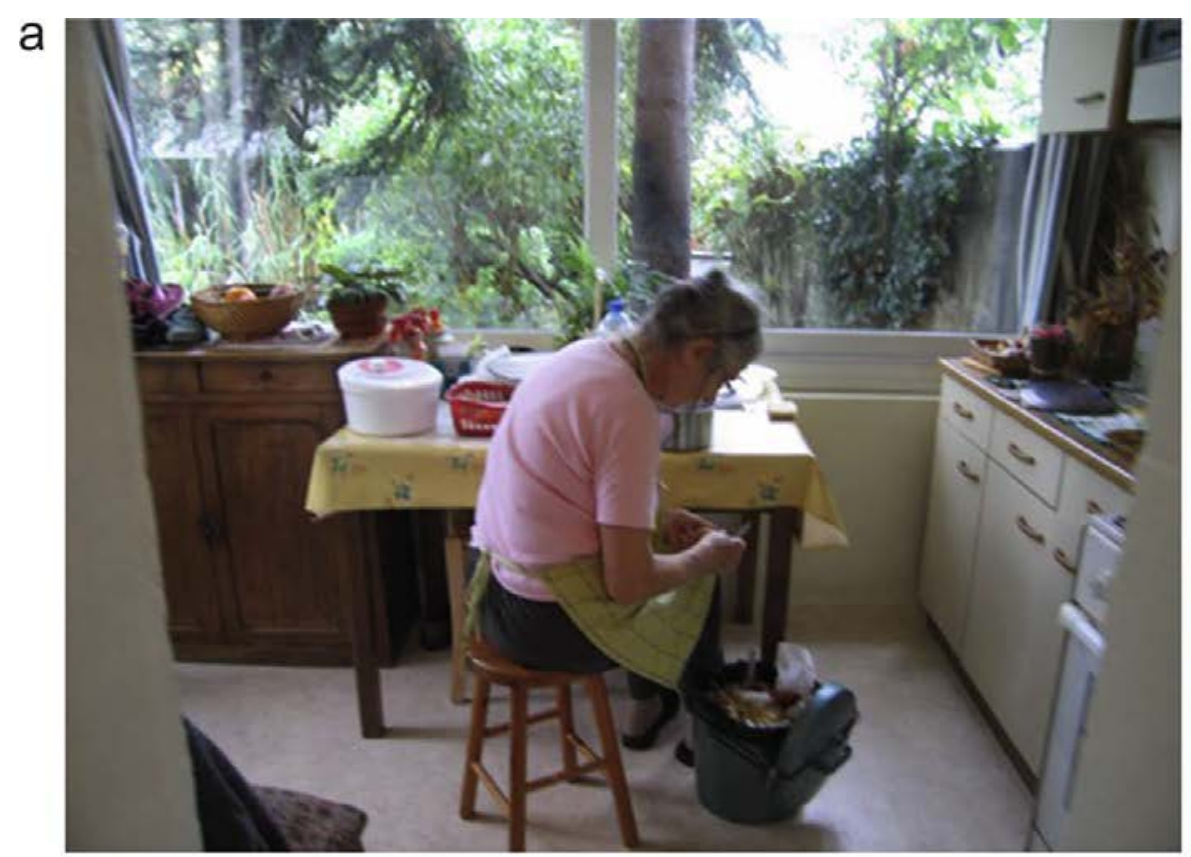

b

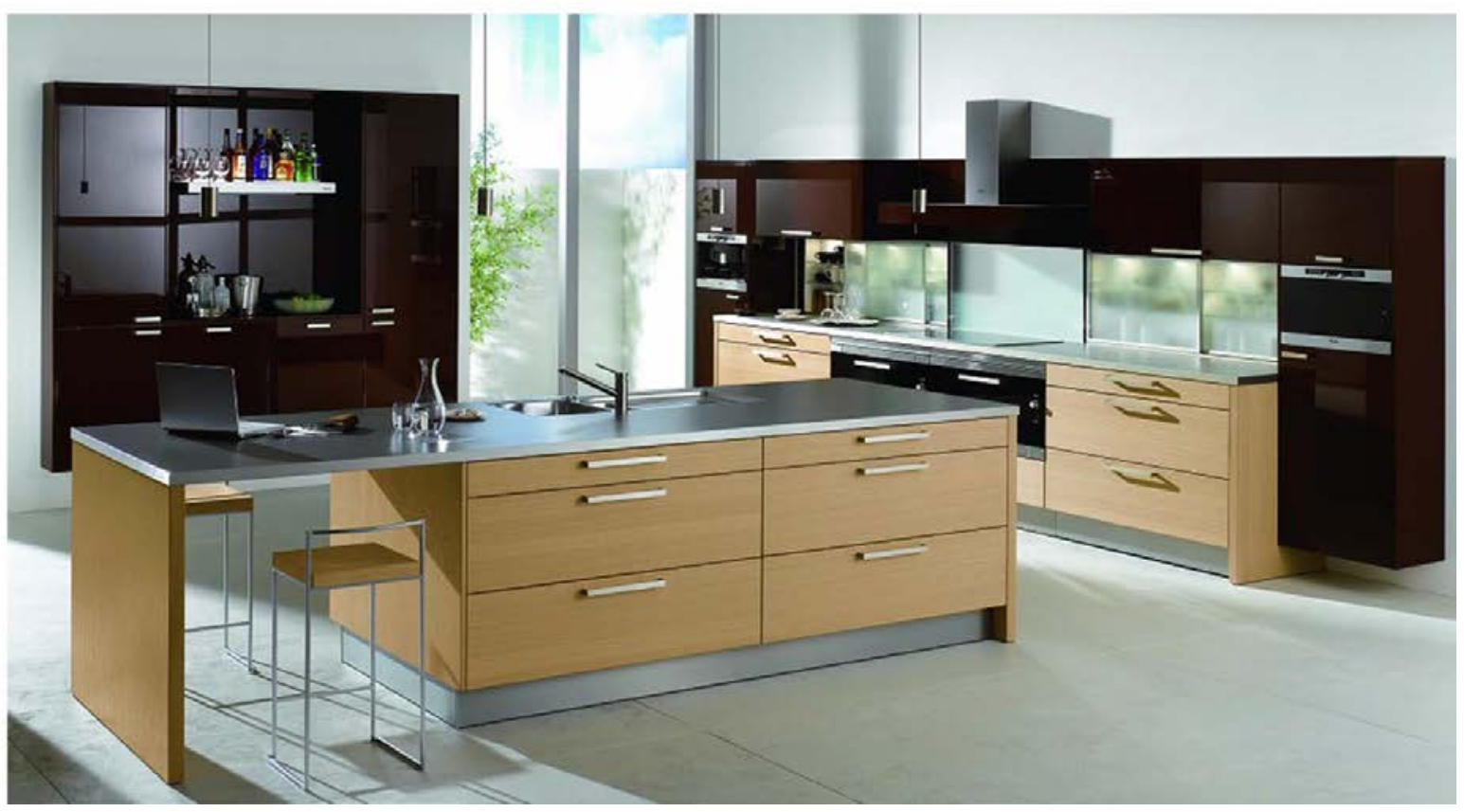

Fig. 1 

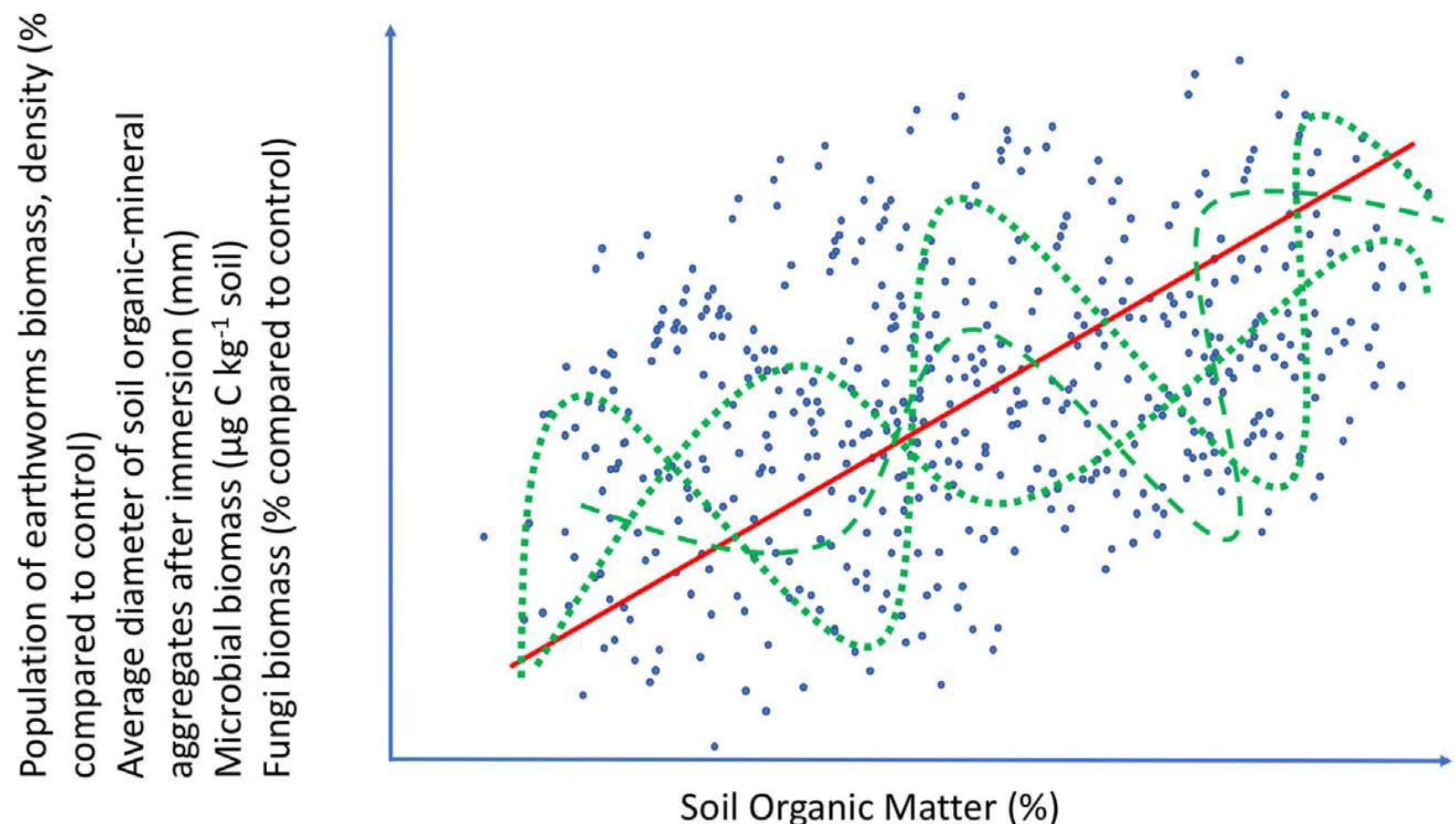

Fig. 2 


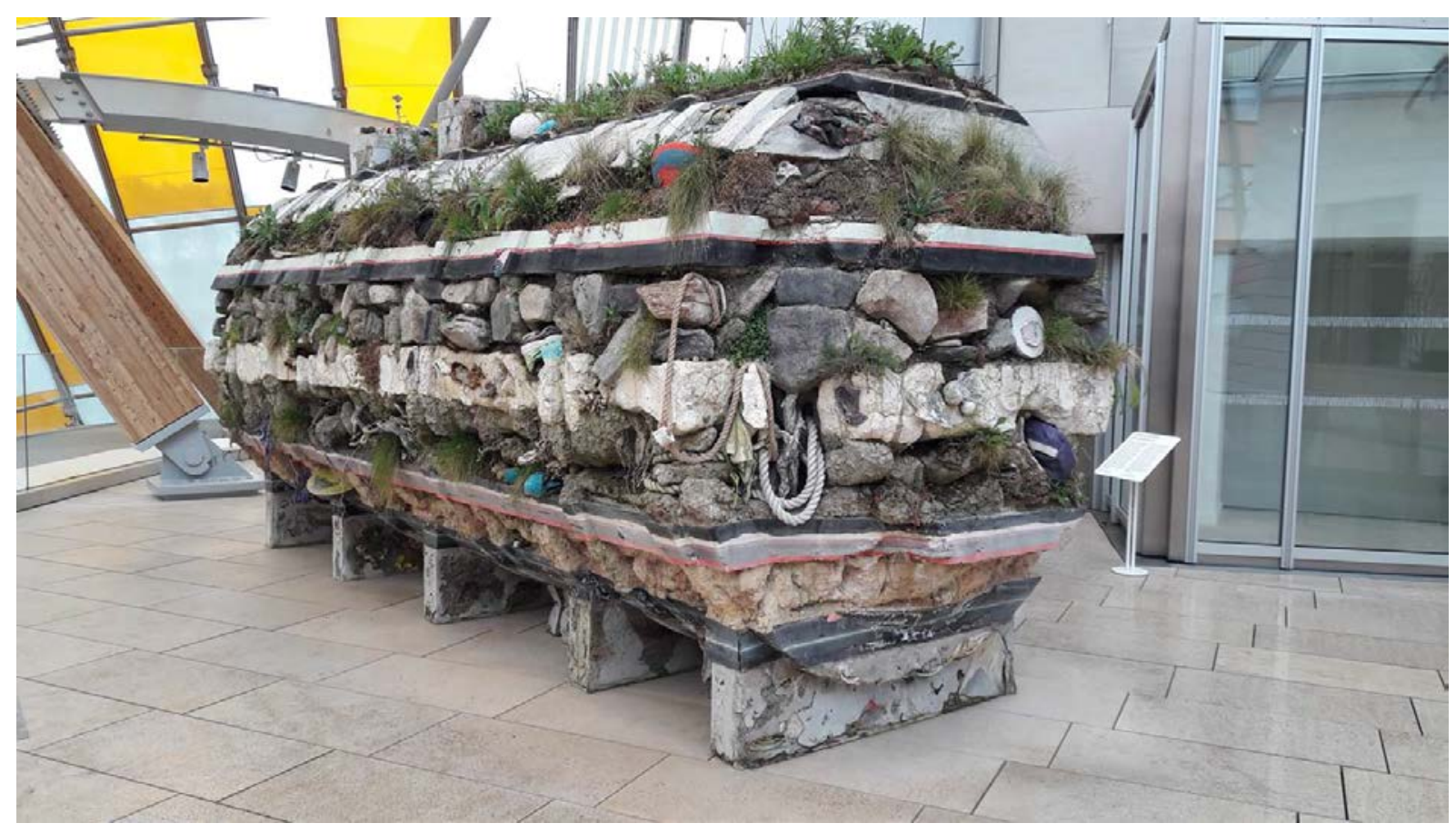

Fig. 3 